III) Nordic Council of Ministers

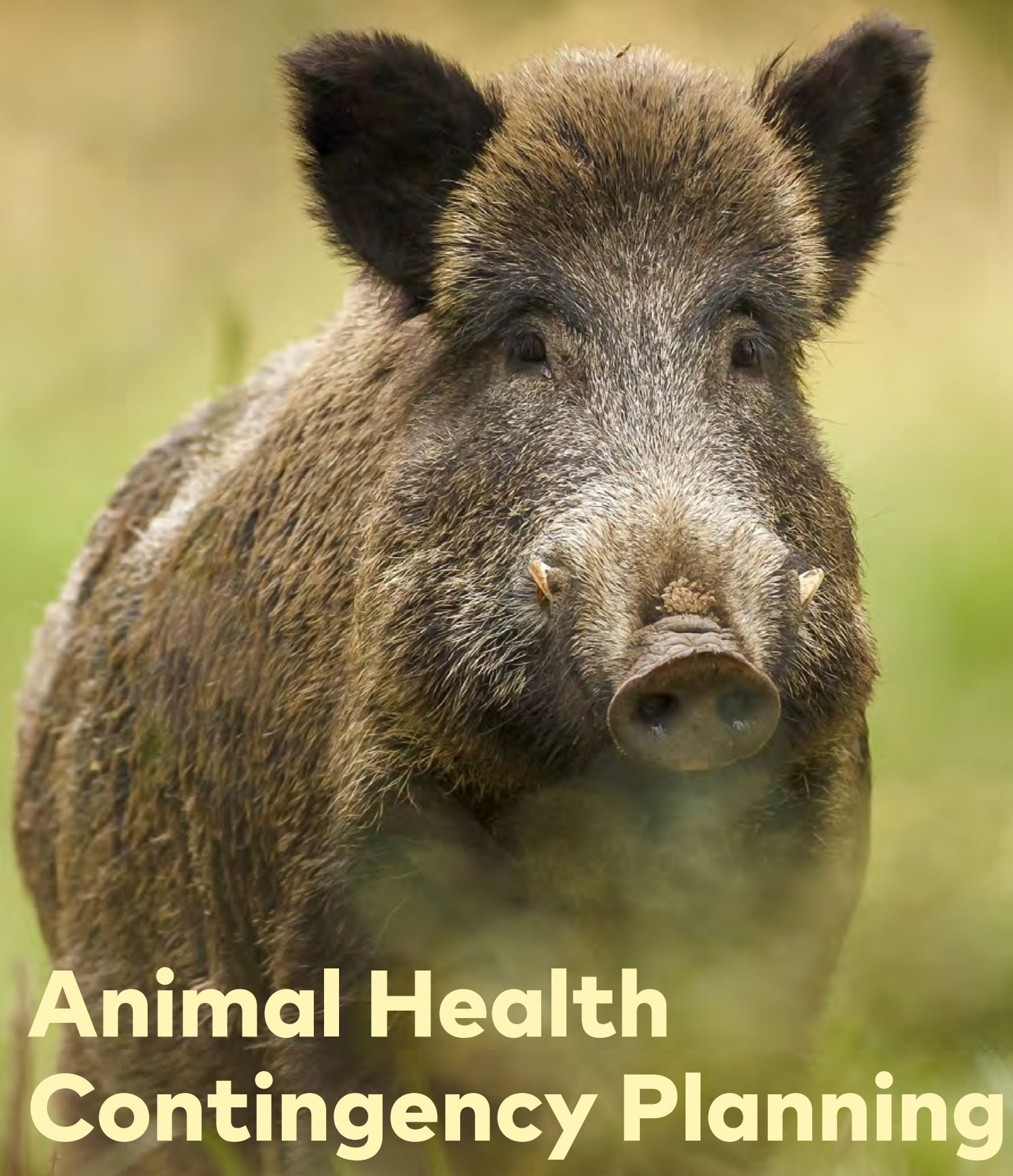

The proceedings of a Seminar on Animal Health Contingency Planning in the Nordic-Baltic Countries, 12-13 October 2016, Vilnius, Lithuania 



\section{Animal Health Contingency Planning}

The proceedings of a Seminar on Animal Health Contingency Planning in the Nordic-Baltic Countries, 12-13 October 2016, Vilnius, Lithuania

Anna Huda and Jørgen Westergaard

TemaNord 2017:539 
Animal Health Contingency Planning

The proceedings of a Seminar on Animal Health Contingency Planning in the Nordic-Baltic Countries, 12-13 October 2016, Vilnius, Lithuania

Anna Huda and Jørgen Westergaard

ISBN 978-92-893-5040-2 (PRINT)

ISBN 978-92-893-5041-9 (PDF)

ISBN 978-92-893-5042-6 (EPUB)

http://dx.doi.org/10.6027/10.6027/TN2017-539

TemaNord 2017:539

ISSN $0908-6692$

Standard: PDF/UA-1

ISO 14289-1

(c) Nordic Council of Ministers 2017

Cover photo: Scanpix

Print: Rosendahls

Printed in Denmark

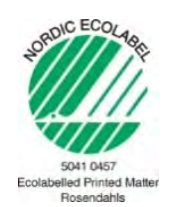

Although the Nordic Council of Ministers funded this publication, the contents do not necessarily reflect its views, policies or recommendations.

\section{Nordic co-operation}

Nordic co-operation is one of the world's most extensive forms of regional collaboration, involving Denmark, Finland, Iceland, Norway, Sweden, the Faroe Islands, Greenland, and Åland.

Nordic co-operation has firm traditions in politics, the economy, and culture. It plays an important role in European and international collaboration, and aims at creating a strong Nordic community in a strong Europe.

Nordic co-operation seeks to safeguard Nordic and regional interests and principles in the global community. Shared Nordic values help the region solidify its position as one of the world's most innovative and competitive. 


\section{Contents}

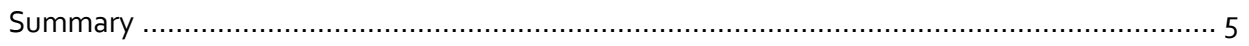

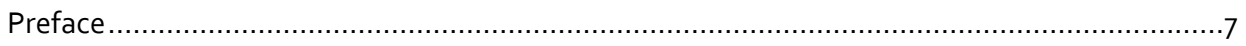

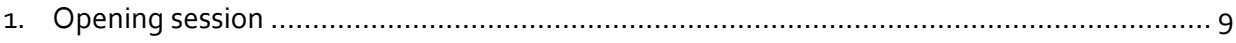

2. Abstracts from invited speakers ...................................................................

2.1 Contingency planning in the Nordic-Baltic countries from 2006-2016 ..................11

2.2 OIE reaching out globally ....................................................................

2.3 The development and application of novel diagnostic methods for detection of infectious viral diseases in domestic animals and in wildlife .................................14

$2.4 \quad$ The use of models in contingency planning …................................................

2.5 Development and application of EuFMD Impact Calculator .............................15

2.6 Animal health contingency planning and sharing of costs ....................................17

2.7 European Commission - planned emergency preparednesss projects for 2017-201917

2.8 Preparedness for natural disasters Role of the veterinary services .........................18

2.9 Preparedness for flooding, an increasing necessity in a changing climate with one

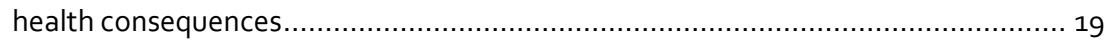

2.10 Preparedness for natural disasters - Landslides ............................................. 19

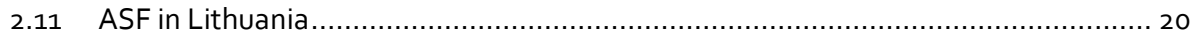

2.12 African swine fever in Latvia: outbreaks, biosecurity measures and trade aspects ....21

2.13 African swine fever virus preliminary results of epidemiological investigations in

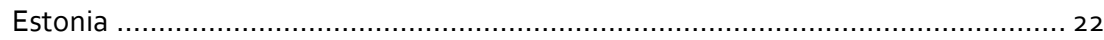

2.14 Countries at ASF threats: Experiences from CVET missions .............................. 22

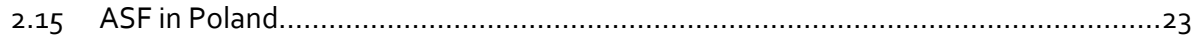

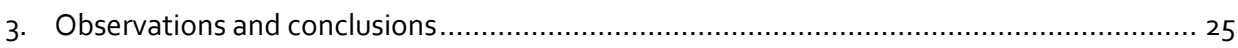

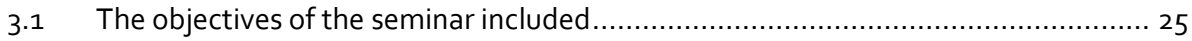

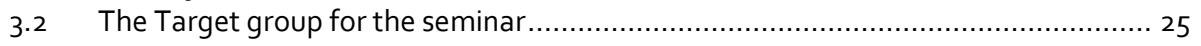

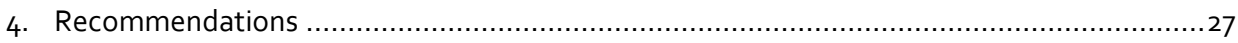

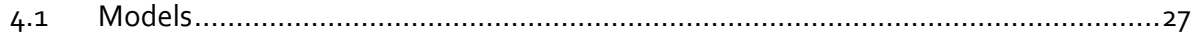

4.2 Value of disease prevention and emergency preparedness .................................27

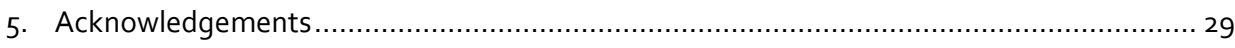

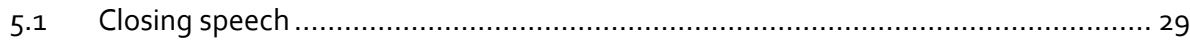

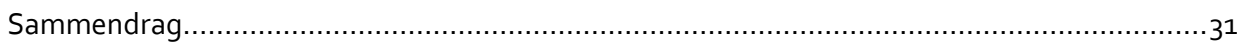

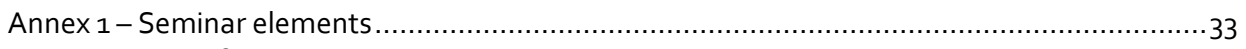

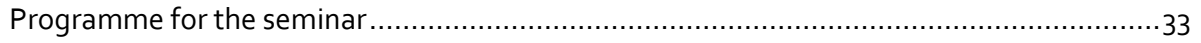

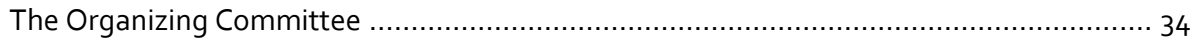

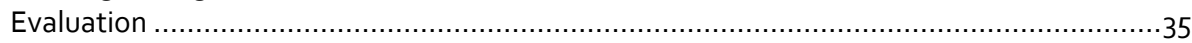

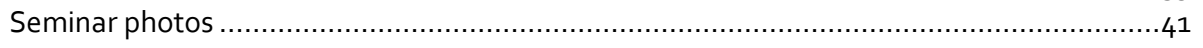

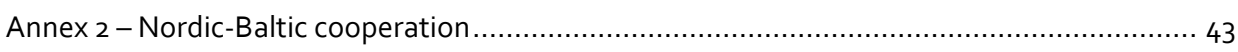

Chapter I - The Nordic-Baltic Animal Health Emergency Reserve ................................. 43

Chapter II - The platform for Nordic-Baltic Veterinary Contingency Planning Studies........ 44

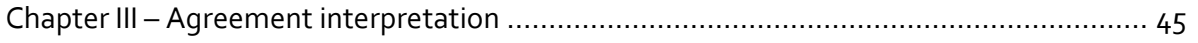




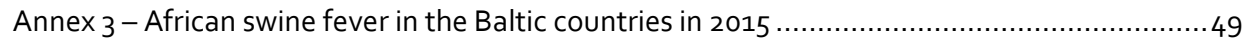

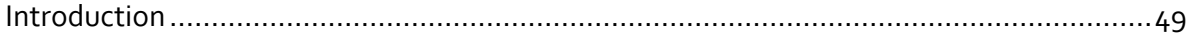

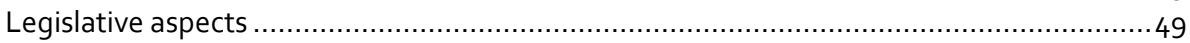

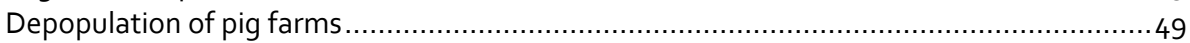

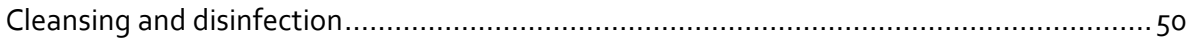

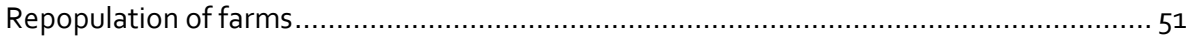

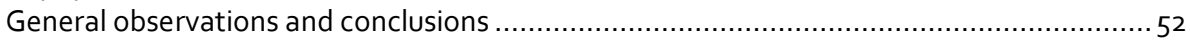

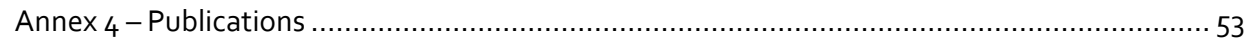




\section{Summary}

The seminar on Animal Health Contingency Planning was held at Holiday Inn, Vilnius, Lithuania on 12th-13th October 2016 and attended by a total of 90 participants coming from 10 countries - Denmark, Estonia, Finland, Iceland, Japan, Latvia, Lithuania, Norway, Poland and Sweden.

The objectives of the seminar included:

- To celebrate 10 years of cooperation within the area of animal health contingency planning in the Nordic-Baltic Region.

- To review the role of globalization and animal health contingency planning in a changing world.

- To highlight and exchange views on modern diagnostic methods, epidemiological models and economics of importance for contingency planning.

- To share knowledge and experiences gained from African swine fever preventive, control and eradication measures in the Baltic countries and in Eastern Europe.

- To address the requirements to veterinary preparedness during natural disasters.

The seminar had speakers coming from the European Commission, the World Organisation for Animal Health (OIE), Denmark, Estonia, Iceland, Latvia, Lithuania, Norway, Poland and Sweden and their presentations provided an excellent basis for valuable exchange of views between the invited speakers and the participants of the seminar and for enhancing network building.

Day one had focus on animal and human health contingency planning in the Nordic-Baltic countries and on novel diagnostic methods, the use of models and economics of contingency planning.

In the late afternoon participants had an opportunity to take part in a guided tour of the old Vilnius and in the evening in a seminar dinner at Vilnius Town Hall.

On day two contingency planning for livestock during natural disasters was highlighted by speakers from Iceland, Sweden and Norway who did present valuable information concerning earthquakes, volcano eruptions, snow storms, flooding, landslides and the role of the veterinary authorities for coping with natural disasters. Prevention, control and eradication measures related to African swine fever in the Baltic countries and in Eastern European countries were covered in great details and the problems caused by the presence of African swine fever in the wild boar were the subject of intensive discussions.

The presentations highlighted the importance of having efficient surveillance and monitoring systems for animal diseases and zoonoses in domestic and wild animals and well developed contingency plans based on the four pillars: prevention, 
preparation, response and recovery. Prevention involves measures to preclude a disease entering a country based on import controls and biosecurity. Preparation involves preparation of and maintaining contingency plans based and training and exercising the plans. Response, when the disease outbreak occurs, to react with the objective to control disease and limit damage. Recovery to return the livestock production and trade conditions back to pre-outbreak conditions.

The participants of the seminar recognized the importance of contingency planning and two recommendations were adopted. One recommendation is having focus on the use of modeling for contingency planning and one having focus on economic and social aspects of contingency planning.

Experiences in the last decade has shown that no country has the capability of ensuring $100 \%$ security of its borders by imposing import bans or quarantine measures on animals and animal products; thus the strategy plan adopted in 2006 by the Nordic Council of Ministers on cooperation within the Nordic-Baltic Countries on preventing and combating serious infectious animal diseases is still very valid. 


\section{Preface}

This publication was prepared as an outcome of the Seminar on Animal Health Contingency Planning in the Nordic - Baltic Countries, 12th-13th October, Vilnius, Lithuania with financial support provided from the Nordic Council of Ministers.

The publication contains the abstracts prepared for the 4 sessions entitled:

- The changing world.

- Contingency planning - the future.

- Contingency planning for livestock during natural disaster.

- African swine fever (ASF) - the Baltic and Eastern European experience.

And in addition information under the headings:

- Observations and conclusions.

- Recommendations.

- Memorandum of Understanding on a Nordic-Baltic Animal Health Emergency Reserve and Nordic-Baltic Veterinary Contingency Planning Studies.

- African swine fever in the Baltic countries in 2015: Information on depopulation, cleansing, disinfection and repopulation.

The seminar was attended by 90 participants coming from 10 countries: Denmark, Estonia, Finland, Iceland, Japan, Latvia, Lithuania, Norway, Poland and Sweden.

The editors gratefully acknowledge the contributions from chair persons, speakers and participants for their help in developing and clarifying ideas valuable for animal health contingency planning.

Figure 1: The logo of the Nordic-Baltic Veterinary Contingency Group

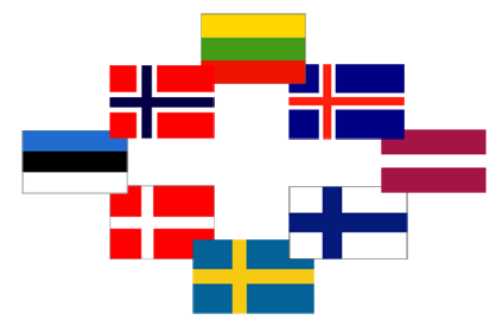





\section{Opening session}

The participants of the seminar were at the opening session welcomed by Deputy Chief Veterinary Officer of Lithuania Dr. Vidmantas Paulauskas and by Dr. Anna Huda, chairman of the Nordic-Baltic Veterinary Contingency Grou.

The opening speech by Dr. Vidmantas Paulauskas is presented below:

"On behalf of the State Food and Veterinary Service I would like to welcome all of you here in Vilnius. For us it is great honor that such anniversary seminar is taking place in our country.

Ongoing serious animal diseases epidemics are highlighting the importance of having wellprepared, highly-trained personnel available to efficiently manage animal disease outbreaks. Such seminars, as we have today, where the experts can meet and share their experience is a very, very valuable tool. I and my colleagues would wish that the Nordic-Baltic Veterinary Contingency Group would continue its activities for long, long years. So, I wish everybody a successful seminar, good discussions, nice social evening.

Thank you."

The speech given by Dr. Anna Huda is presented below:

"On behalf of the Nordic-Baltic Veterinary Contingency Group, I warmly welcome you all to this seminar.

Firstly, I would like to thank our Lithuanian friends and colleagues for inviting us to have the seminar here in Vilnius. I would like to thank the Lithuanian veterinary administration, and especially Deputy Chief Veterinary Officer Dr. Vidmantas Paulauskas, Rima Živatkauskaite and Paulius Busauskas, for the invaluable support in the preparations of this seminar that marks the 10year anniversary of the cooperation between the National veterinary administrations of the Nordic and Baltic countries.

I am proud to welcome a long row of most competent speakers from Denmark, Estonia, Iceland, Latvia, Lithuania, Norway, Poland, and Sweden. We can promise the audience a high quality of presentations with the aim to enhance a constructive and fruitful exchange of views on the many challenges facing contingency planning.

What is the background and the purpose of the group behind this event, you might wonder? Ten years ago, in 2006, the Nordic Council of Ministers adopted a strategy which included plans of a closer cooperation between the Nordic and Baltic countries in the field of veterinary contingency planning. This strategy emphasized that exotic animal infectious diseases, with zoonotic potential as well as emerging diseases, should be prioritized. Subsequently, the Nordic-Baltic Veterinary Contingency Group was established.

The primary objective of the group is to improve cooperation, communication and exchange of information and experience between the veterinary authorities within the Nordic-Baltic region, in the context of contingency planning and during animal disease crises.

Secondary objective is to increase awareness of epizootic diseases among professionals and stakeholders within the region, identify areas of improvement in contingency planning and also to obtain and spread knowledge related to fighting infectious animal diseases by building bridges within the Nordic-Baltic region and on international level. 
In order to reach these goals, the group has arranged a number of activities during the years. Those include international simulation exercises on epizootic diseases, seminars with invited speakers, expert meetings, training activities and observer activities on international exercises.

This seminar could not take place without the financial support from the Nordic Council of Ministers.

The group consists of members from the veterinary authorities of the eight Nordic and the Baltic countries. The group members keep a close contact through e-mails, skype-meetings and at least three regular meetings every year. Fortunately, the membership of the group has been quite stable, which contributes to a productive and efficient performance.

I would now like to introduce you to the current members of the Nordic-Baltic Veterinary Contingency Group: Paulius Busauskas from Lithuania, Edvins Olsevskis from Latvia, Maarja Kristian from Estonia, Audur Arnthorsdottir from Iceland, Siri Løtvedt from Norway, Elisabet Lindal from Sweden, and, the former chairman of the group, Sirpa Kiviruusu from Finland. And last but not least our invaluable consultant Dr. Jørgen Westergaard, who has been our support in all of our efforts from the very beginning. Jørgen is also the main organizer of this seminar programme and has led the preparations with great competence and enthusiasm. Further, we have had competent assistance from our Danish secretary, Anne Jyderup, during the preparatory work. Thank you all for your commitment to the preparations of this seminar.

During the seminar, we will look into the effect of globalization and climate change on animal and human health, contingency planning in the Nordic-Baltic countries with special reference to novel diagnostic methods, and the use of models and economics of contingency planning.

Tomorrow morning, we will look into contingency planning for livestock during natural disaster and in the afternoon session on the prevention, control and eradication of African swine fever.

My hope is that this seminar will contribute to building bridges and networking with colleagues and experts in the field of animal health. Furthermore, I sincerely hope that you will enjoy the seminar and that you will leave with new knowledge as well as new contacts in the countries within our Nordic-Baltic region.

I wish you all a fruitful and inspiring seminar.

Thank you." 


\title{
2. Abstracts from invited speakers
}

\author{
2.1 Contingency planning in the Nordic-Baltic countries from \\ 2006-2016 \\ Dr. Jørgen M. Westergaard, ADC-Consult, Denmark
}

The Nordic Council of Ministers - the official body for Nordic intergovernmental cooperation - adopted in 2006 a strategy plan which included cooperation within Nordic-Baltic veterinary contingency planning. The aim of the plan was to maximize the potential of Nordic/Baltic cooperation and work together to prevent and combat serious contagious animal diseases such as foot and mouth disease, avian influenza, classical swine fever, Newcastle disease and any other animal disease, including zoonoses. The implementation of the plan was taken up by a Nordic-Baltic Veterinary Contingency Group (N-BVCG) which with regard to administrative aspects reports to the Nordic working group for microbiology and animal health/animal welfare. The objectives of the N-BVCG include:

- to improve cooperation, communication and exchange of information and experiences, between the veterinary authorities within the Nordic-Baltic region, in the context of contingency planning and during animal diseases crises

- to increase awareness among professionals and stakeholders within the region regarding animal health threats and emerging diseases.

It is vital to detect an exotic animal disease as soon as possible and before it spreads. The activities initiated by the N-B VCB have included attempts to enhance animal health contingency planning taking into account the pre-epidemic phase, the epidemic phase and the post-epidemic phase occurring during disease outbreaks. The activities have in particular been:

- International seminars; the topics have included risk analysis, vector borne diseases, risk based surveillance and contingency planning; wildlife and infectious animal diseases, biosecurity

- International simulation exercises covering the following diseases: foot and mouth disease, bluetongue, West Nile fever, African swine fever and viral haemorrhagic septicaemia 
- Workshops covering: Preparation of simulation exercises, animal expert groups and rapid qualitative risk assessments for use in National veterinary administrations and communication.

The aim of the strategy plan adopted in 2006 is still very valid; outbreaks in the Nordic -Baltic region of exotic diseases such as avian influenza, bluetongue and African swine fever has highlighted the importance of up-dated contingency plans and the value of working together at regional level. Future challenges related to contingency planning will be highlighted.

\subsection{OIE reaching out globally}

Dr. Kazimieras Lukauskas, OIE Regional Representative in Moscow, Lithuania

The need to fight animal diseases at global level led to the creation of the Office International des Epizootics through the international Agreement signed on January 25th 1924. In May 2003, the Office became the World Organisation for Animal Health but kept its historical acronym OIE.

The OIE is the intergovernmental organisation responsible for improving animal health worldwide.

It is recognised as a reference organisation by the World Trade Organization (WTO) and now, in 2016, it has 180 Member Countries. The OIE maintains permanent relations with other international and regional organisations and has 5 Regional and 7 sub-regional Offices on every continent, 313 OIE Reference Centres, 262 Reference Laboratories, 51 Collaborating centres.

The day-to-day operation of the OIE is managed at the Headquarters situated in Paris and placed under the responsibility of a Director General elected by the World Assembly of Delegates.

Monique Eloit is the Director General for the period of 2015-2020.

Since it was created, the OIE has played a key role in its capacity as the sole international reference organisation for animal health, enjoying established international recognition and benefiting from direct collaboration with the Veterinary Services of all its Member Countries. As a mark of the close relationship between animal health and animal welfare, the OIE has become, at the request of its Member Countries, the leading international organisation for animal welfare.

Since 1990, the OIE has adopted a five-year strategic planning cycle for its work programme. Now, the Sixth Strategic Plan covers the period 2015-2020.It builds on the success of previous Strategic Plans. Within the 6th Strategic Plan, a special emphasis is placed on the economic prosperity, social and environmental welfare of population; Protecting animals - Preserving our future. 
Three strategic objectives of the 6th Strategic plan are:

- Security.

- Trust.

- Capacity.

In the current trend of globalization where unprecedented movements of commodities and people are used by pathogens to colonize the entire planet and that nowadays, pathogens are transported around the world faster- than the average incubation time of most animal diseases, the OIE's general strategy is to advance governance of Veterinary Services. As a global public good, Veterinary Services must be able to act and react within an effective, structured national legislative framework, and be provided with the appropriate financial and human resources to enforce it. OIE assists Member Countries with strengthening governance of their animal health systems, and bring them in compliance with OIE standards on quality using the OIEPVS Pathway including the Gap Analysis tool. This tool provides guidance for preparing five year operational budgets for country Veterinary Services based on their initial PVS evaluation and identified national priorities, and allows determining the tasks and human, physical and financial resources required to enable National Veterinary Services to function in an optimal manner and to comply with international standards of quality. This support to the Veterinary Services also includes addressing laboratory diagnosis capacity.

How Veterinary Services can be effective, what are the key elements? Firstly, it is the early detection and rapid response to animal disease outbreaks that prevent natural or intentional biological disasters and facilitate trade flows and contribute to global food security. Secondly, there must be an alliance between public and private sectors, also biosecurity measures must be taken, as vaccination of animals when it is appropriate. Thirdly, compensation mechanisms have to be set, so everyone would feel safe in case of worst situation.

Fourthly, a national chain of command and a clear structure of management have to be set and finally, education of veterinarians and research are one of the key elements that have to be taken into account when talking about the development of veterinary policies.

Furthermore, it is vital that the international organizations cooperate in sharing responsibilities and coordinating global activities to address health risks at the animalhuman-ecosystems interfaces in order to secure a safe environment for all of us. This concept was also stressed in the Ministerial Declaration - of $\mathrm{G}_{2} \mathrm{O}$ Agriculture Ministers Meeting (June 2011) where it was stated: We encourage international organizations, especially FAO, the World Health Organization (WHO), the World Organization for Animal Health (OIE), the Codex Alimentarius Commission (Codex), the international plant protection Convention (IPPC) and WTO to continue their efforts towards enhancing interagency cooperation. 
Finally, when thinking about the global objectives and aims of OIE, it must be said that OIE will continue supporting the Members by setting internationally recognised standards and guidelines in animal health veterinary public Health and animal welfare while protecting biodiversity disseminating scientific and animal health information; recognising disease free status of countries/zones; providing technical and political support for good governance and Veterinary Services using PVS Pathway and other capacity building activities; providing support to Veterinary Education; supporting the improvement of the quality and organisation of the Veterinary profession and public/private partnership; influencing governments for better recognition of the key role of veterinarians in society.

\subsection{The development and application of novel diagnostic methods for detection of infectious viral diseases in domestic animals and in wildlife}

Dr. Mikael Leijon, Section for Bioinformatics and Molecular Biology, Department of Microbiology, National Veterinary Institute (SVA), The OIE Collaborating Centre for the Biotechnology-based Diagnosis of Infectious Diseases in Veterinary Medicine, Sweden

Pathogenic microorganisms are recognized by their unique nucleic acid sequence typically by means of polymerase chain reactions utilizing sequence specific primers and probes. However, the mere detection of the microbe is in many cases not sufficient. It is also necessary to determine the pathogenicity to achieve a complete diagnosis. This is the case for avian influenza virus (AIV) where highly pathogenic variants differ critically at the hemagglutinin cleavage site from low pathogenic viruses. The complexity and great variability of this cleavage site has until now made nucleotide sequencing necessary for pathotyping. Here we show that novel PCR based assays can be designed to enable pathotyping of AIV and other viruses and thus allow simple PCR tests in a field setting for complex diagnosis. We also show an evaluation of a portable PCR platform for ASF during outbreaks in an endemically infected pig population.

\subsection{The use of models in contingency planning}

Dr. Anette Boklund, Tariq Halasa, Technical University of Denmark, National Veterinary Institute, Denmark

During the last decades, the use of models in relation to outbreaks of contagious diseases in Europe has increased, especially driven by the large outbreaks of CSF in the Netherlands in 1997/98 and of FMD in England in 2001 and 2007. The interest in learning from our past has driven epidemiologist's to compare what was actually done 
during the outbreaks, with what could have been done and how differences in choice of strategy and availability of resources could have changed an epidemic.

However, outbreaks of contagious diseases can be divided in two steps, the introduction of disease into a susceptible population, and the spread of disease, first within the infected herd and later between herds. The objective of the presentation will be to present how models have been used in Northern Europe.

A stochastic simulation model, called DTU-DADS, has been used to simulate spread of FMD and ASF in Denmark.

In previous studies, the model has predicted that from an epidemiological and economic point of view pre-emptive culling of neighboring herds is most often beneficial in the Danish situation. However, relatively small epidemics can be controlled using the basic control strategy, while very large epidemics might become less expensive with a vaccination strategy. Furthermore, one Danish study showed that combining these strategies with surveillance zones enlarged to $15 \mathrm{~km}$ would result in shorter duration of the epidemics and reduced costs.

ASF has a high mortality rate, and therefore left-overs from dead animals must be considered when spread of ASF is modelled. Therefore, a new model was developed for spread of ASF within herds and included in the DTU-DADS-ASF model. This model predicts that outbreaks of ASF in Denmark will be of limited size and duration, however still with a considerable economic impact.

\title{
2.5 Development and application of EuFMD Impact Calculator
}

\author{
Dr. Malin Grant, Swedish Board of Agriculture, Sweden
}

Foot-and-mouth disease (FMD) is a highly contagious trans-boundary viral disease that affects cloven-hoofed animals with devastating social and economic impacts.

The economic effects of FMD are not equal across the globe. To effectively assess the impact of an outbreak one needs to take into consideration the size of the susceptible animal population, the type of livestock production systems, value chains present and the ripple effects on the wider economy.

To assist decision-making on FMD control an FMD impact calculator was developed, for the rapid assessment of an outbreak based on readily available data. This takes the form of a deterministic economic model and provides estimates of the impact of an outbreak and the costs of the outbreak response in a country that was free from FMD. Through a decision-tree approach the model gives an indicator of the most economically favourable strategy to control the outbreak. Impact is modelled considering information on the livestock sector, relevant value chains and epidemiological inputs. Estimates of the costs of different control strategies and associated losses are produced using readily available data. It does not take into consideration the more complex and uncertain ripple effects of an epidemic across the livestock sector and the wider economy. It is recognised that attempting to predict 
such impacts can be important and are contemplated qualitatively. This considers possible consequences and likelihood, while allowing users to express judgement on whether it could be a major concern.

Together the quantitative cost model and the qualitative assessment provides a powerful but simple method of quickly assessing control options assisting decision making during an outbreak or as part of a contingency planning process.

It is anticipated that the FMD Impact Calculator will link to other epidemiological and economic models to make more accurate predictions on the wider economic impacts of an FMD outbreak. 


\subsection{Animal health contingency planning and sharing of costs \\ Dr. Sten Mortensen, Danish Veterinary and Food Administration, Denmark}

In Denmark, 0.5 million cattle and 18.5 million pigs were slaughtered and 9 million pigs were exported in 2013. A total of 27 Foot and Mouth Disease (FMD)/ swine fever (SF) preventive activities were identified. The estimated total costs amounted to EUR 32 million in 2013 . The single most costly FMD/SF related activity, amounting to EUR 8 million or $26 \%$ of total costs, was a national legal requirement to clean lorries immediately after transportation of live animals. The following expenses in decreasing order were 2) establishing and continuously cleaning of farm facilities after delivery of live animals; 3 ) publicly funded FMD certified laboratory. Low costs were found of testing of suspicious clinical symptoms and of border controls of private imports of meat. The distribution of costs between stakeholders was estimated to be as follows: pig industry $63 \%$, cattle industry $27 \%$, and the public authorities $10 \%$. Most of the activities focused on reducing the probability of spreading FMD/SF, while only a few activities were directed mainly towards reducing the probability of introduction of disease. Legally required FMD/SF activities (mainly based on EU legislation) accounted for $60 \%$ of the activities, while FMD/SF related measures agreed on at sector level and measures implemented due to individual initiatives, such as farmer's investment in specially built facilities as part of a farm biosecurity plan, each accounted for $20 \%$.

\subsection{European Commission - planned emergency preparednesss projects for 2017-2019}

Dr. Lena Englund, European Commission, Directorate-General for Health and Food Safety, Directorate for Health and Food Audits and Analysis, Sweden

During the past 17 years the European Commission has carried out more than 60 audits on animal disease contingency planning in EU Member States (MS) and countries preparing to become EU MS. Several audits evaluated the actual implementation of the contingency plan during real outbreaks. The outcomes of these audits have been discussed, and experiences shared, in workshops organized by the Commission and an overview report of the most recent series is under preparation. It is evident from the published audit reports (http://ec.europa.eu/food/audits-analysis/audit_reports/index.cfm) that contingency planning has developed over time and that MS are better prepared to deal with animal disease emergencies now than when the series started. In 2017, the focus of audits will be on the implementation of legally required measures and the operability of contingency plans during recent outbreaks in the EU. 
One priority area of Directorate-General for Health and Food Safety is general emergency preparedness. Within this framework a new project (2017-2019) in Directorate for Health and Food Audits and Analysis will study interdisciplinary emergency preparedness for veterinary matters in relation to disasters causing destruction of infrastructure and/or large-scale evacuation of people and animals (e.g. floods, forest fires, earthquakes, chemical accidents). Such emergency preparedness needs to establish and practice effective interoperability between several competent authorities and non-governmental organizations in order to prevent spread of zoonotic diseases and minimize negative effects on food safety, animal welfare, animal health, and feed supply. The project will be carried out in cooperation with other Commission services and will include questionnaires to all or selected MS, existing reports from simulation exercises (animal health, veterinary public health, public health), and visits to selected MS with experiences in this field. The plan is to present the results as a report and a workshop.

\subsection{Preparedness for natural disasters Role of the veterinary services}

\section{Dr. Audur Lilja Arnthorsdottir, Icelandic Food and Veterinary Authority, Iceland}

According to guidelines for national veterinary services, recently developed by the World Organisation for Animal Health (OIE), the objectives for the veterinary services in disaster management are to protect animal health and welfare, safeguard human and environmental health and assist the countries in restoring and enhancing economic and societal conditions. In the guidelines it is also stated that the veterinary services play a leadership role in advising the authorities on animal health, animal welfare and veterinary public health, and that they are responsible for providing input to policies and disaster management plans on these subjects, provide training for private veterinarians and animal owners, and ensure that all stakeholders receive warning information. In line with the guidelines, the veterinary services should also conduct risk analysis to identify hazards, assess the risk and decide on risk management and risk communication. Part of the risk management is to develop contingency plans for each type of event identified by the risk assessment. The guidelines describe the tasks by means of a commonly used disaster management model, which is a cycle divided into four main phases: A mitigation and prevention phase, a preparedness phase, a response phase and a recovery phase.

In recent years, Iceland has encountered several natural emergencies. The hazards connected to the events have been of various sorts; i.e. ash downfall, air pollution, floods, collapsing of buildings etc. The scale of consequences depends not only on the sort of event but also where and when it occurs. The Icelandic Food and Veterinary Authority has developed a generic contingency plan regarding animal 
health, animal welfare and veterinary public health matters. Specific guidelines for different kinds of events are gradually being built into the plan, based on experiences.

\title{
2.9 Preparedness for flooding, an increasing necessity in a changing climate with one health consequences
}

\author{
Dr. Johan Waldner, Swedish Board of Agriculture, Sweden
}

As global warming goes on we have seen a lot of extraordinary weather situations in all parts of the world. Flooding over rural areas is one of several events with a great impact on both agriculture and on society as a whole. The preparedness for flooding ranges from flood mapping, embankment and reserving areas as flood plains to maintaining rescue resources on farm, local, regional and national levels. Flooding can happen along rivers and lakes but also almost anywhere after heavy downpours. After flood events the most obvious risks for infection from a zoonotic point of view are the parasite Cryptosporidium and bacterias as Salmonella, VTECIEHEC and to a certain extent Bac. Anthracis. Cryptosporidium have several pathogenic species. C. hominis is just pathogenic for people whereas $C$. parvum infects young bovine calves and has also zoonotic capabilities. Salmonella can spread through water and also remain on a flooded pasture after the water has withdrawn. When animals come to graze perhaps months later they can be infected and spread the disease to other animals and humans although the infective dose is quite high. VTEC/EHEC, the strains of E. Coli that produce toxins that sometimes cause serious disease to people, has also proved in Sweden to be able to contaminate cultured lettuce through irrigation. Bacillus anthracis has ability to spread through water and tend to float long distances on the surface without being diluted. The disease Anthrax is not easily transmitted to humans but is of course a potentially severe zoonotic disease. Although the possibilities for diseases exist, there are mostly other consequences of floods that are more important from a health point of view.

\subsection{Preparedness for natural disasters - Landslides \\ Dr. Siri Margrete Løtvedt, Norwegian Food Safety Authority, Norway}

The steep hills and mountainsides and narrow fjords of Norway are beautiful, but they also provide a risk for landslides. One specific kind of landslide, the rockslide, a fallout of large rock volumes, especially into a fjord followed by a tsunami, is the worst case scenario with a potential to kill many people and animals and inflict serious damage to property and infrastructure. 
Experience shows that rockslides develop over time. The predictability is the basis for the monitoring, warning and evacuation that constitute the main elements of preparedness against rockslides. The contingency planning is designed to prevent loss of life and health. If possible, it also takes into account the environment and material assets.

The Norwegian Water Resources and Energy Directorate (NVE) is the owner of the National contingency plan for rockslides. More than 20 other authorities are involved in the emergency preparedness work and the handling of such incidents. Cooperation and coordination are therefore vital, and are thoroughly described in the National contingency plan. This plan describes activities, involvement and cooperation in the normal situation (green) and for all the phases during an incident, moderate danger (yellow), high danger (orange) and extreme danger (red).

The Norwegian Food Safety Authority (NFSA) is the authority for, among others, food safety, drinking water, animal (including fish) health and welfare. NFSA and many of the other authorities mentioned in the national plan, have their own sector specific plan. In the NFSA Contingency plan for natural disasters, specific measures for each phase are described, and also a recommendation for the work after an incident.

\subsection{ASF in Lithuania}

Dr. Vidmantas Paulauskas, Deputy Chief Veterinary Officer, State Food and Veterinary Service, Lithuania

On 24th of January in 2014 Lithuania notified two primary cases of African swine fever (ASF) in wild boars: one male animal 12 months old was hunted on the 22nd of January $5 \mathrm{~km}$ away from the border with Belarus and one female animal 3 years old was found dead on the 2oth of January in 2014 about $40 \mathrm{~km}$ to the north from the border with Belarus. The distance between the two animals was about $36 \mathrm{~km}$. The animals were tested positive for the ASF virus (ASFV) genome by real time PCR at the National Reference Laboratory for ASF in Lithuania (NRL). The results were confirmed by the European Reference Laboratory for ASF (CISA-INIA, Madrid, Spain). Furthermore, the genotyping revealed that the Lithuanian isolates were identical with the ASFV isolates from Georgia (2007), Armenia (2007), Azerbaijan (2008), Russia (2008-2012), Ukraine (2012) and Belarus (2013). All wild boars being hunted and discovered dead in the infected area were sampled and tested for the presence of ASF antibodies and genome using ELISA and RT-PCR. In total, there were 45 cases in wild boars and 6 outbreaks were registered in 2014, also 111 cases in wild boars and 13 outbreaks were registered in 2015 . It should be noted that only 1 outbreak was registered in a commercial farm and other outbreaks were registered in noncommercial farms with low biosecurity measures. Since 2011 Lithuania has prepared and confirmed biosecurity measures for commercial and non-commercial farms. 
Based on the practice of 3 years it can be stated that the implementation of high biosecurity measures is one of the main requirements to prevent farms from ASF. Also, close cooperation in all countries which are affected by ASF and the common strategy is the main aim in order to control this disease.

\subsection{African swine fever in Latvia: outbreaks, biosecurity measures and trade aspects}

Dr. Edvins Oḷ̌sevskis, Food and Veterinary Service, Latvia

The first cases of African swine fever (ASF) in wild boar in Latvia were registered in June 2014 on the border with Belarus. As a consequence of virus spread in a local wild boar population several ASF outbreaks in backyard pig farms were registered in Latvia. In total, by the end of the year 217 cases in wild boar and 32 outbreaks in pig farms were registered.

In 2015, natural spread of ASF virus in wild boar population was observed in the same territories infected in 2014. In total, 1,048 cases in wild boar and 10 outbreaks in backyard pig farms were registered in 2015.

During the summer 2016, further spread of ASF virus in wild boar population occurred covering about $70 \%$ of the country. By the end of August 2016, 765 cases in wild boar and 2 outbreaks in small pig farms were registered.

So far, all outbreaks in pig farms were detected in areas where ASF was present in wild boar population and during the summer (June-August) that can be considered as high risk period.

The biosecurity requirements for pig farms were approved after ASF detection in Latvia. For commercial farms the implementation of the biosecurity plan is mandatory but owners of non-commercial farms (backyards) must fulfil a list of biosecurity requirements. All pig farms are inspected every year (1-2 times) to verify the implementation of biosecurity requirements.

Trade restrictions for live pigs and pig meat are determined by the Commission Implementation decision 2014/709/EU. Initially, restrictions for trade were very strict but since December 2015 several derogations are available. However, activities of pig farms located in areas where ASF in wild boar is present are still very restricted. 


\title{
2.13 African swine fever virus preliminary results of epidemiological investigations in Estonia
}

Maarja Kristian, DVM; Imbi Nurmoja, DVM; Helen Prommik, DVM. Veterinary and Food Board, Estonia

The first confirmed ASF wild boar case in Estonia was 08.09.2014 in south part and the first confirmed ASF case in northern of Estonia was 18.09.2014. The first confirmed ASF domestic pig outbreak in Estonia was 21.07.2015. It took less than month that ASF spreaded from the south part of Estonia to the North part and almost one year to reach from the forest to the farms. In the Southern part the mortality of wild boars was high, a lot of cases were reported, where in one place more than one dead animal (up to 16), most of cases laboratory result were ASFV (PCR) positive and ASFV ab negative. In the Northeast mortality was low, no cases reported, where was more than one dead animal, most of cases laboratory results were ASFV (PCR) negative and ASFV ab positive. Roughly $10 \%$ of ASF positive wild boars have been ab positive. Circulating ASFV is $100 \%$ homologous with the virus isolated from wild boars and domestic pigs in Latvia, Lithuania and Poland in 2014, and with the ASF virus isolated in Belarus in 2013 (Bel13/Grodno). Virus can remain in one pen or part of the building for 1-2 weeks or even more without being noticed. Not all pigs in affected pen will be infected. First symptoms can be very mild and unspecific like anorexia, unwillingness to stand, pigs of the affected pen are silent, no clear temperature reaction always. Severe disease was observed in $\sim 50 \%$ of outbreaks. Often starts in sows (with piglets), low or very low morbidity and usually occurring during the summer (seasonality). Generally the main cause of outbreaks was biosecurity mistakes.

\subsection{Countries at ASF threats: Experiences from CVET missions}

\author{
Dr. Ago Pärtel, Private expert, CVET missions and BTSF trainings, Estonia
}

Serious classical swine fever, foot and mouth disease and avian influenza epidemics in the past have highlighted the importance of having well-prepared, highly-trained personnel available to efficiently manage animal disease outbreaks. With the aim of being able to provide the Member States of the EU and non-EU countries with a list of experts the European Commission adopted in 2007 a legal base for a Community Veterinary Emergency Team (CVET). Experts on the list have special knowledge and expertise within one or more of the areas of epidemiology, virology, management of disease eradication programmes, laboratory diagnostics, organization of veterinary services, risk analysis, wildlife and any other relevant field for animal disease control. The list contains in 2016 the names of 116 experts and during the period 2007-2016 there have been close to 50 CVET missions. 
The presentation will provide information on CVET missions to Romania, Moldova and Hungary in relation to African swine fever threats.

The terms of reference for the missions have been:

To provide scientific, technical, managerial and practical on-the-spot assistance for the development of the most suitable preventive and control measures for African swine fever under local conditions.

Especially as regards, wildlife management, movement restrictions, border control, surveillance, diagnostic capability and biosecurity.

The program for an African swine fever CVET mission will be organized by the host country and usually include visits to the central veterinary authority, the national Africa swine fever laboratory, a regional veterinary authority, commercial and noncommercial gig farms and hunting areas.

The results obtained by a mission are discussed with the veterinary authorities of the host country and the European Commission and presented to Member States through the Standing Committee on Plants, Animals, Food and Feed. The presentation is made available on the website of the European Commission.

\subsection{ASF in Poland}

Dr. Krzysztof Jażdżewski, General Veterinary Inspectorate, Poland

In Poland, the first cases of African swine fever (ASF) were recorded in wild boar in February 2014 in the northeastern part of the country, close $(<1 \mathrm{~km})$ to the border with Belarus and the first outbreak of ASF in domestic pigs was diagnosed on 27 July 2014. The domestic pig holding was located about $2.5 \mathrm{~km}$ from the border with Belarus and it had 8 pigs, only. Until October 2016 the disease has been recorded in wild boar and domestic pigs as shown in the table below.

Table 1: African swine fever cases in wild boar and outbreaks in domestic pigs recorded in Poland YEAR Cases in wild boar Outbreaks in domestic pigs

$\begin{array}{lrr}2014 & 30 & 2 \\ 2015 & 53 & 1 \\ 2016(12 \text { October) } & 31 & 20 \\ \text { Total } & 114 & 23\end{array}$

The presentation will include information on the geographical distribution of the recorded cases and outbreaks of ASF. 
The wild boar population has increased in recent years and is currently estimated to 264,000 . The increase in the past decade (prior to detection of ASF) appears to be caused by:

- Global warming:

- Lower mortality in winter.

- Increased frequency of acorn production of oak and beech trees (> nutritional base).

- Increase in cropland related to maize production.

- Winter feeding.

- Varying hunting effectiveness.

- Species-specific factors: high plasticity to adapt to changing habitats.

The presentation will highlight steps taken to decrease the number of wild boar.

The epidemiological investigations carried out has shown that an enhancement of biosecurity practices of pig holdings is crucial for minimizing the risk for virus spillover from wild boar to domestic pigs followed long-distance spread of ASF - virus by human related activities. ASF-virus isolates have been subjected to DNA sequencing and analysis; the genetic characteristics of Polish strains of ASF-virus, as well as geographic distribution of ASF cases, support the working hypothesis that the origin of Polish strains of ASF-virus to be in Belarus.

The standard control and eradication measures are those given in Council Directive 2002/60/EC. 


\section{Observations and conclusions}

The seminar on Animal Health Contingency Planning in the Nordic-Baltic countries Subtitle: Contingency planning for animal diseases and natural disasters - was held at Holiday Inn, Vilnius, Lithuania from 12-13 October 2016.

\subsection{The objectives of the seminar included}

- To celebrate 10 years of cooperation within the area of animal health contingency planning in the Nordic-Baltic Region.

- To review the role of globalization and animal health contingency planning in a changing world.

- To highlight and exchange views on modern diagnostic methods, epidemiological models and economics of importance for contingency planning.

- To share knowledge and experiences gained from African swine fever preventive, control and eradication measures in the Baltic countries and in Eastern Europe.

- To address the requirements to veterinary preparedness during natural disasters.

\subsection{The Target group for the seminar}

The seminar addresses personnel with special responsibilities in animal health preparedness and contingency work, in particular:

- Persons / Institutions involved in contingency planning within the area of animal health.

- Veterinarians employed by national governments designated to handle animal disease emergencies and food safety.

- Diagnosticians from national reference laboratories covering infectious animal diseases.

- Veterinarians employed by the livestock industry responsible for disease prevention, control and eradication.

- Representatives of veterinary medical association.

The seminar was very well attended by veterinarians from the target group and it had a total of 90 participants coming from 10 countries - Denmark, Estonia, Finland, Japan, Iceland, Latvia, Lithuania, Norway, Poland and Sweden. 
The presentations given during the seminar were by speakers coming from the European Commission, the World Organisation for Animal Health (OIE), Denmark, Estonia, Iceland, Latvia, Lithuania, Norway, Poland and Sweden. The presentations provided an excellent basis for:

- a valuable exchange of views between the invited speakers and the participants of the seminar

- $\quad$ network building.

Day one had focus on animal and human health contingency planning in the NordicBaltic countries and on novel diagnostic methods, the use of models and economics of contingency planning In the late afternoon participants had an opportunity to take part in a guided tour of the old Vilnius and in the evening in a seminar dinner at Vilnius Town Hall. The Presidency of the Nordic Council of Ministers is in 2016 held by Finland and the dinner speech was given by Ambassador Mr. Christer Michelson, the Embassy of Finland in Vilnius.

On day two contingency planning for livestock during natural disasters was highlighted by speakers from Iceland, Sweden and Norway who did present valuable information concerning earthquakes, volcano eruptions, snow storms, flooding, landslides and the role of the veterinary authorities for coping with natural disasters. Prevention, control and eradication measures related to African swine fever in the Baltic countries and in Eastern European countries were covered in great details and the problems caused by the presence of ASF in the wild boar were the subject of intensive discussions.

The discussions on day 1 and day 2 showed a great interest for enhancing cooperation during animal disease emergencies and for the threats caused by the presence of African swine fever in the wild boar population in the Eastern European Countries. Additional information on the topics is given in the annexes 1-3 under the headings:

- Memorandum of Understanding on a Nordic-Baltic Animal Health Emergency Reserve and Nordic-Baltic Veterinary Contingency Planning Studies.

- Report on the workshop: Strengthening and adaptation of the preventive measures to existing risks of African swine fever introduction from Eastern neighbouring countries to Nordic-Baltic region held in Sigulda (Latvia) - 29th-31st October 2012.

- African swine fever in the Baltic countries in 2015: Information on depopulation, cleansing, disinfection and repopulation. 


\section{Recommendations}

\subsection{Models}

The participants of the seminar recognized the importance of modeling for contingency planning and the implementation of simulation exercises.

It is recommended that the N-B VCG encourages:

- The collection and sharing of relevant field data for use in modeling.

- The cooperation between scientists and others in the Nordic and Baltic countries involved in modeling within the area of veterinary medicine.

\subsection{Value of disease prevention and emergency preparedness}

A general approach for measuring the value of contingency plans in the area of animal health is to some extend missing.

It is recommended that the N-B VCG explore the possibility of addressing the gap, by organizing sessions on costs and benefits, including social aspects, related to:

- Biosecurity at farm level.

- Simulation exercises.

- Contingency plan. 



\section{Acknowledgements}

The Nordic-Baltic Veterinary Contingency Group wishes to thank the Nordic Council of Ministers for the political support and the financial support made available for the preparation, implementation and valuation of the seminar on Animal health Contingency Planning.

The support made it possible for the national experts from the Nordic and Baltic countries to meet with representatives of international organizations and discuss topics of mutual interest within the context of contingency planning related to infectious animal disease and natural disaster emergencies and at the same time the seminar gave the participants an opportunity to celebrate 10 years of cooperation in the Nordic Baltic region in the field of veterinary medicine.

A special thank shall be addressed to all the speakers for the well prepared presentations, the chairmen managing competently the different sessions and to all the participants for active contributions to the success of the seminar. The NordicBaltic Veterinary Contingency Group is convinced that many valuable networks have been established for future work of importance for animal disease preparedness and contingency planning.

The seminar would not have been a success without the valuable support given by Dr. Vidmantas Paulauskas, the Deputy Chief Veterinary Officer of Lithuania, Mr. Deividas Kliučinskas, the Chief Veterinary Officer of Lithuania and the staff of the State Food and Veterinary Service, Lithuania.

\subsection{Closing speech}

The closing speech given by Dr. Anna Huda is presented below.

"On behalf of the Nordic-Baltic Veterinary Contingency Group, I would like to thank the "State Food and Veterinary Service" of Lithuania for hosting this event, for organizing an excellent social programme, and taking care of all practical details.

The seminar would not have been a success without the valuable support given by the Deputy Chief Veterinary Officer of Lithuania, Dr. Vidmantas Paulauskas, Rima Živatkauskaite and Paulius Busauskas, from the "State Food and Veterinary Service," Vilnius.

The Nordic-Baltic Veterinary Contingency group wishes to thank the Nordic Council of Ministers for their financial support made available for the preparation and implementation of this seminar. The support has made it possible for national experts to meet here in Vilnius to discuss the many subjects that did arise in connection to the different sessions of the seminar.

I would also like to thank the conference manager at the Hotel Holiday Inn for excellent corporation during the preparatory work for this seminar and for the excellent service during the seminar. 
A special thank goes to the speakers for giving excellent and well-prepared presentations and contributing to very interesting discussions, and to the chairmen managing the different sessions and leading us through the programme in a most competent way.

Finally, I would like to thank all delegates for your active participation, for contributing to fruitful discussions and exchange of views. I am confident that our exchange of views will be beneficial to future contingency planning in the veterinary services of the Nordic-Baltic region.

I hope that you have been inspired by the interesting discussions and that you leave with an extended professional network.

I wish you all a safe journey home.

Thank you." 


\section{Sammendrag}

Seminaret omhandlende det veterinære beredskab blev afholdt på Holiday Inn, Vilnius, Litauen den 12.-13. oktober 2016 med 90 deltagere fra 10 lande: Danmark, Estland, Finland, Island, Japan, Letland, Litauen, Norge, Polen og Sverige.

Formålet med seminaret omfattede:

- At fejre 10 års samarbejde i den Nordisk - Baltiske Region vedrørende det veterinære beredskab.

- At gennemgå betydningen af globalisering og det veterinære beredskab i en verden under forandring.

- At belyse og udveksle synspunkter vedrørende moderne diagnostiske metoder, epidemiologiske modeller og økonomiske forhold af betydning for et beredskab.

- At dele viden og erfaringer indhentet fra foranstaltninger vedrørende forebyggelse, kontrol og bekæmpelse af Afrikansk svinepest i de Baltiske lande og i det østlige Europa.

- At adressere behovet for det veterinære beredskab i forbindelse med natur katastrofer.

Seminaret havde foredragsholdere, der kom fra Europa-Kommissionen, Verdens Organisation for husdyrsygdomme (OIE), Danmark, Estland, Island, Letland, Litauen, Norge, Polen og Sverige. Foredragsholdernes indlæg gav et glimrende grundlag for udveksling af synspunkter imellem foredragsholderne og seminarets øvrige deltagere og for øget udbygning af netværk.

Programmet for dag 1 havde fokus på beredskab på det humane og det veterinære medicinske område i de Nordiske og Baltiske lande, brug af epidemiologiske modeller samt økonomiske forhold vedrørende beredskabet. Deltagerne havde sent på eftermiddagen mulighed for at deltage i en bytur i det gamle Vilnius og om aftenen at deltage i seminar-middag på Vilnius rådhus.

På dag 2 blev beredskabet i forbindelse med natur katastrofer belyst af foredragsholdere fra Island, Norge og Sverige. Disse gav værdifulde oplysninger vedrørende jordskælv, vulkanudbrud, oversvømmelser og jordskred og veterinær administrationers rolle i forbindelse med at klare natur katastrofer. Foranstaltninger vedrørende forebyggelse, kontrol og bekæmpelse af Afrikansk svinepest i de Baltiske og østeuropæiske lande blev detaljeret behandlet, og problemerne forårsaget af forekomsten af Afrikansk svinepest i vildsvin var et emne for intens diskussion.

Indlæg fra foredragsholdere belyste betydningen af et effektivt overvågnings- og registrerings-system for husdyrsygdomme og for zoonoser hos husdyr og i den vilde fauna og for veludviklede beredskabsplaner på grundlag af 4 søjler: forebyggelse, 
forberedelse, respons og rehabilitering. Forebyggelse indbefatter, at sygdomme hindres adgang til et land ved hjælp import kontrol og smittebeskyttelses foranstaltninger. Forberedelse indbefatter udarbejdelse og vedligeholdelse af det veterinære beredskabs planer ved hjælp af undervisning og beredskabsøvelser. Respons, når et sygdomsudbrud forekommer, indebærer en reaktion med det formål at kontrollere sygdommen og begrænse skaderne. Rehabilitering omfatter etablering af husdyrproduktion og handelsforhold, som svarer til situationen forud for et sygdomsudbrud.

Seminarets deltagere anerkendte betydningen af et beredskab, og to anbefalinger blev godkendt. En havde fokus på brug af modeller i beredskabsarbejdet og én på økonomiske og sociale aspekter vedrørende beredskab.

Erfaringer indhøstet i de seneste 10 år, har vist, at intet land har evnen til sikre sine grænse $100 \%$ ved at etablere import forbud og karantæne foranstaltninger for levende dyr og produkter af animalsk oprindelse. Dette betyder, at strategiplanen vedtaget af Nordisk Råd in 2006 vedrørende samarbejde indenfor de Nordisk-Baltiske lande vedrørende forebyggelse og bekæmpelse af smitsomme sygdomme hos dyr stadig er velbegrundet. 


\section{Annex 1 - Seminar elements}

\section{Programme for the seminar}

- Time: 12th and 13th of October, 2016.

- Place: Hotel Holiday Inn, Vilnius, Lithuania.

\section{Target groups}

The seminar addresses anyone who performs activities within areas related to animal disease awareness, preparedness, control measures and contingency planning.

\section{Table 2: Programme. Day 1, 12th October - Arrival of participants}

\begin{tabular}{|c|c|}
\hline \multicolumn{2}{|l|}{ Time } \\
\hline $8.30-9.15$ & Registration \\
\hline 9.15 & $\begin{array}{l}\text { Opening session by Dr. Vidmantas Paulauskas, Deputy Chief Veterinary Officer, Lithuania, and } \\
\text { Dr. Anna Huda, President of the Nordic-Baltic Veterinary Contingency Group, Denmark }\end{array}$ \\
\hline \multicolumn{2}{|c|}{ Session I The changing world Chairman: Dr. Vidmantas Paulauskas } \\
\hline $9 \cdot 30$ & $\begin{array}{l}\text { Contingency planning in the Nordic-Baltic countries 2006-2016. Speaker: Dr. Jørgen Westergaard, ADC- } \\
\text { Consult, Denmark }\end{array}$ \\
\hline 10.00 & OIE reaching out globally. Speaker: Dr. Kazimieras Lukauskas, OIE Regional Representative in Moscow \\
\hline 10.45 & Questions and discussion related to Session I \\
\hline 11.00 & Coffee break \\
\hline \multicolumn{2}{|c|}{ Session II Contingency planning - the future Chairman: Dr. Sirpa Kiviruusu, Finland } \\
\hline 11.20 & $\begin{array}{l}\text { The development and application of novel diagnostic methods for detection of infectious viral diseases } \\
\text { in domestic animals and in wildlife. Speaker: Dr. Mikael Leijon, SVA, Sweden }\end{array}$ \\
\hline 12.00 & The use of models in contingency planning. Speaker: Dr. Anette Boklund, DTU, Denmark \\
\hline $12.40-13.00$ & Questions and discussion related to the first two presentations in Session II \\
\hline $13.00-14.00$ & Lunch \\
\hline 14.00 & $\begin{array}{l}\text { Development and application of EuFMD Impact Calculator. Speaker: Dr. Malin Grant, Swedish Board } \\
\text { of Agriculture, Sweden }\end{array}$ \\
\hline $14 \cdot 30$ & $\begin{array}{l}\text { Animal health contingency planning and sharing of costs. Speaker: Dr. Sten Mortensen, Danish } \\
\text { Veterinary and Food Administration, Denmark }\end{array}$ \\
\hline 15.20 & $\begin{array}{l}\text { European Commission - planned emergency preparedness projects for 2017-2019. Speaker: Dr. Lena } \\
\text { Englund, European Commission, Grange }\end{array}$ \\
\hline 15.40 & Questions and discussion related to day 1 (Session I and II) \\
\hline 16.00 & Coffee break \\
\hline $17.00-18.30$ & Optional guided walk; starts at Holiday Inn and ends at Vilnius Town Hall \\
\hline 19.00 & Dinner at Vilnius Town Hall \\
\hline
\end{tabular}


Table 3: Programme. Day 2, 13th October

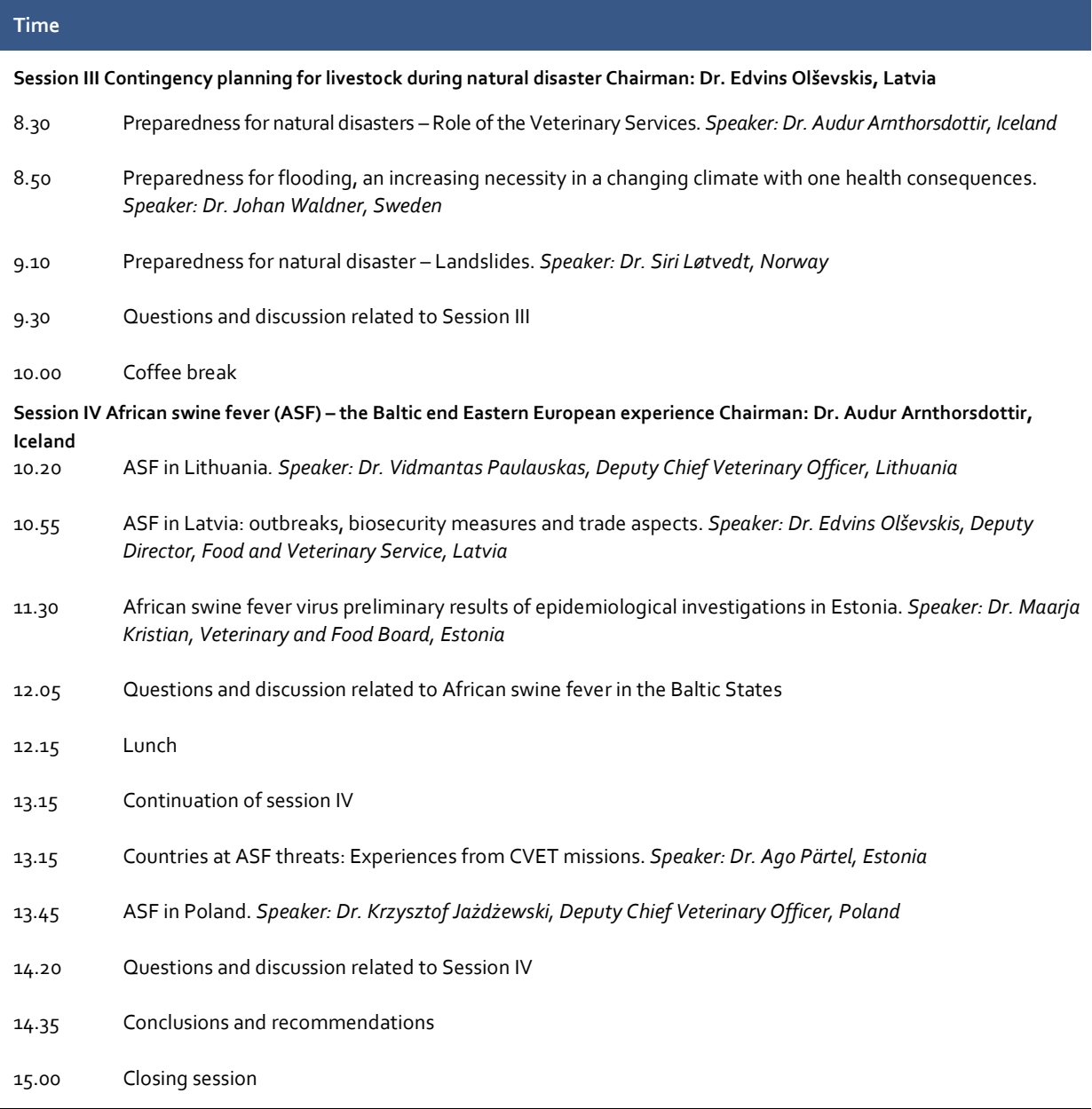

\section{The Organizing Committee}

The seminar was organized by the Nordic-Baltic Veterinary Contingency Group having the following members:

- Anna Huda, Danish Veterinary and Food Administration, Denmark.

- Marja Kristian, Veterinary and Food Board, Estonia.

- Sirpa Kiviruusu, Evira, Finland.

- Audur Arnthorsdottir, Food and Veterinary Authority, Iceland.

- Edvins Olsevskis, Food and Veterinary Services, Latvia.

- Paulius Bušauskas, State Food and Veterinary Service, Lithuania.

- Rima Živatkauskaitè, State Food and Veterinary Service, Lithuania. 
- Siri Løtvedt, The Norwegian Food Safety Authority, Norway.

- Elisabet Lindal, Swedish Board of Agriculture, Sweden.

- Jørgen Westergaard, ADC-consult, Denmark. ${ }^{1}$

\section{Evaluation}

An evaluation form was a part of the handouts given to all participants at the time of registration. The form consisted of three sections:

- General questions.

- Evaluation of the presentations.

- Complementary comments.

The evaluation scale to be used during the evaluation was $1-5$, where $1=$ poor and $5=$ excellent. The completed evaluation forms, total of 33, were collected at the end of the seminar, and the information was compiled. Information and feedback from the forms is highlighted below.

\section{Table 4: General questions}

\section{General question}

\section{$\begin{array}{llllll}1 & 2 & 3 & 4 & 5 & \text { N.a. }\end{array}$}

1 Did the seminar meet your expectations in relation to networking and sharing experiences?

2 Did you feel you had the necessary prerequisites to be able to benefit from the seminar?

3 The choice of topics for the different sessions was relevant.

$4 \quad$ How did you find the supplied material, handouts, etc.?

5 The seminar has improved my knowledge about contingency planning and ASF control measures.

$\begin{array}{llllll}0 & 0 & 4 & 18 & 11 & 0 \\ 0 & 0 & 2 & 10 & 21 & 0 \\ 0 & 0 & 4 & 15 & 14 & 0 \\ 1 & 1 & 5 & 13 & 10 & 3 \\ 0 & 0 & 4 & 14 & 14 & 1 \\ 0 & 0 & 2 & 14 & 16 & 1\end{array}$

Note: N.a.: No answer. Ad Table 1. From the answers received to the general questions it is clear that the participants by and large used 4 or 5 on the evaluation scale. To the question "Over all how did you find the seminar", $91 \%$ of the participants rated as 4 or 5 , a result that must be considered as very satisfactory.

Registration to the seminar was administered via a website. In the seminar management plan and in the "Guidelines for abstracts and presentations" it was scheduled that abstracts should arrive not later than 1st September, and PowerPoint presentations not later than $15^{\text {th }}$ September. Abstracts and presentations from the speakers were published as soon as they were received by the organizing committee.

${ }^{1}$ Employed by the organizing committee as private consultant. 
However, many of the speakers were not able to send their PowerPoint presentations beforehand or provided them very late. Thus it was not possible for the participants to gain access to many of the presentations until the day of the seminar or after the seminar. On the other hand, the Seminar website was kept open after the seminar with all documents related to the seminar (abstracts, presentation, conclusions, participants etc.) available.

Table 5: Evaluation of the presentations

\begin{tabular}{|c|c|c|c|c|c|c|c|}
\hline & Evaluation of sessions & 1 & 2 & 3 & 4 & 5 & N.a. \\
\hline 1 & Session I: The changing world. & o & 3 & 7 & 15 & 7 & 1 \\
\hline 2 & Session II: Contingency planning - the future. & o & o & 3 & 20 & 10 & o \\
\hline 3 & Session III: Contingency planning for livestock during natural disaster. & o & 4 & 10 & 10 & 9 & 0 \\
\hline 4 & Session IV: ASF - the Baltic and Eastern European experience. & o & o & 1 & 13 & 19 & 0 \\
\hline
\end{tabular}

Note: Ad Table 2. All four sessions appears to have been well received with slightly lower points for session III on contingency planning for livestock during natural disaster. The scores, using 4 or 5 on the evaluation scale, for the different sessions were: Session I, 67\%; Session II, 91\%; Session III, 58\%; Session IV, $97 \%$.

With regard to complementary comments the participants were invited to respond to the aspects or issues listed under the following five headings:

- Comments (in particular on points where your answer was negative) (13 comments).

- Which PowerPoint presentation was of most interest to you? (22 comments).

- What was the best part of the seminar? (18 comments).

- What could be improved? (16 comments).

- Suggestions for activities to be dealt with by the Nordic-Baltic Veterinary Contingency Group in 2015 or 2016 (12 comments).

The handwritten comments (a total of 81) made by the participants with regard to the presentations and discussions during the different sessions and to the management of the seminar were very valuable and re-enforced the views expressed in the two tables shown above. The comments for instance concerned compliance with the time schedule, somewhat overloaded presentations, the availability of the presentations on the website, more time for discussion. Examples on issues with positive remarks are: the session on contingency planning - the future, the session on African swine fever, networking and discussions with colleagues from other countries, the venue and the social programme. 
With regard to topics for future seminars or workshops or activities a number of topics were mentioned including:

- Stakeholder collaboration and communication.

- Illegal animal import and veterinary cooperation over borders.

- Import export issues. How harmonized are we? How do we combat animal diseases at our borders?

- How to handle e.g. culling and destruction.

- Exotic zoonoses/diseases in pets and zoo animals, "one health".

- New exotic diseases.

- How do we deal with Mycoplasma bovis?

- How do we deal with paratuberculosis?

- ASF, wild boars population, behavior, biosecurity.

- Avian/swine influenza.

- Lumpy skin disease.

- Bluetongue.

- West Nile fever.

- Further exploring of emerging diseases: lumpy skin disease, chronic wasting disease. 
Figure 1: Organization chart

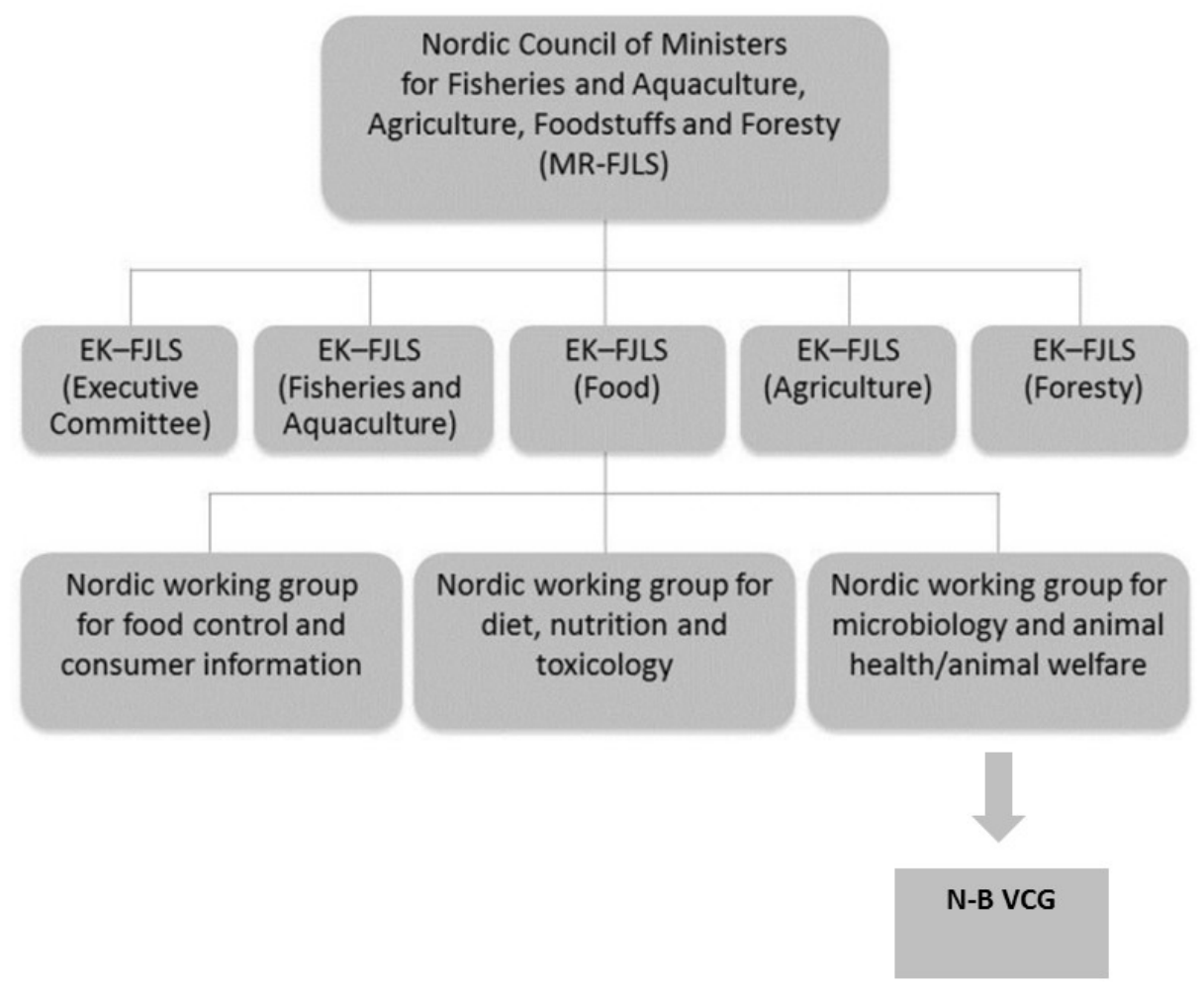

Note: The activities of the Nordic-Baltic Veterinary Contingency Group (N-B VCG) are carried out within the framework of allocations given to Nordic working group for microbiology and animal health/animal welfare.

Table 6: List of participants

Country/Number Name

Email

Denmark

$\begin{array}{lll}1 & \text { Anna Huda } & \text { anxu@fvst.dk } \\ 2 & \text { Lasse Holm } & \text { laho@fvst.dk } \\ 3 & \text { Signe Balslev } & \text { sbal@fvst.dk } \\ 4 & \text { Jens Munk Ebbesen } & \text { jme@lf.dk } \\ 5 & \text { Majbritt Birkmose } & \text { mab@fvst.dk } \\ 6 & \text { Maren Holm Johansen } & \text { mhjo@fvst.dk } \\ 7 & \text { Bente Pedersen } & \text { bpe@fvst.dk } \\ 8 & \text { Flemming Kure Marker } & \text { flkm@fvst.dk } \\ 9 & \text { Bertel Strandbygaard } & \text { bstr@vet.dtu.dk } \\ 10 & \text { Jesper Valbak } & \text { jeva@fvst.dk } \\ 11 & \text { Anne Jyderup } & \text { anjd@fvst.dk } \\ 12 & \text { Conni Madsen } & \text { cohm@fvst.dk } \\ 13 & \text { Susanne Rasmussen } & \text { sura@fvst.dk } \\ 14 & \text { Lisbeth Harm Nielsen } & \text { Lhn@lf.dk }\end{array}$




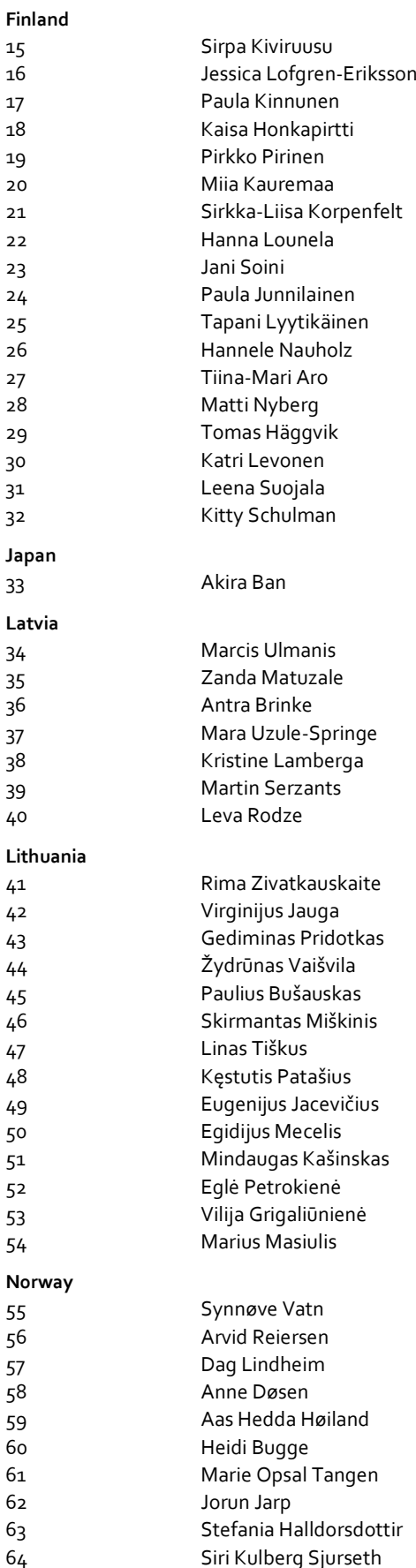

sirpa.kiviruusu@evira.fi jessica.lofgren-eriksson@avi.fi Paula.Kinnunen@evira.fi kaisa.honkapirtti@avi.fi pirkko.pirinen@avi.fi miia.kauremaa@evira.fi sirkka-liisa.korpenfelt@evira.fi hanna.lounela@avi.fi jani.soini@avi.fi paula.junnilainen@avi.fi tapani.lyytikainen@evira.fi hannele.nauholz@ett.fi tiina-mari.aro@evira.fi matti.nyberg@avi.fi tomas.haggvik@kokkola.fi katri.levonen@mmm.fi leena.suojala@mtk.fi kitty.schulman@evira.fi

akira.ban@mofa.go.jp

Marcis.Ulmanis@pvd.gov.Iv zanda.matuzale@zm.gov.lv antra.brinke@zm.gov.lv Mara.Uzule-Springe@pvd.gov.lv Kristine.Lamberga@pvd.gov.lv martins.serzants@pvd.gov.lv ieva.rodze@bior.lv

rzivatkauskaite@vet.It synnove.vatn@animalia.no Arvid.Reiersen@mattilsynet.no dag.lindheim@tine.no andos@mattilsynet.no hehaa@mattilsynet.no Heidi.Bugge@mattilsynet.no maota@mattilsynet.no jorun.jarp@vetinst.no sthal@mattilsynet.no siri.sjurseth@vetinst.no 


\begin{tabular}{|c|c|c|}
\hline Country/Number & Name & Email \\
\hline \multicolumn{3}{|l|}{ Sweden } \\
\hline 65 & Suha Mohammad & suha.mohammad@jordbruksverket.se \\
\hline 66 & Ann Lindberg & ann.lindberg@sva.se \\
\hline 67 & Cecilia Hultén & \\
\hline 68 & Catrin Molander & catrin.molander@jordbruksverket.se \\
\hline 69 & Johanna Dahlström & johanna.dahlstrom@jordbruksverket.se \\
\hline 70 & Thomas Svensson & thomas.svensson@dv.sjv.se \\
\hline 71 & Ebba Schwan & ebba.schwan@gardochdjurhalsan.se \\
\hline 72 & Elisabet Lindal & elisabet.lindal@jordbruksverket.se \\
\hline 73 & Anna Ohlson & anna.ohlson@vxa.se \\
\hline \multicolumn{3}{|l|}{$\begin{array}{l}\text { Speakers } \\
\text { Denmark }\end{array}$} \\
\hline 74 & Anette Boklund & anebo@vet.dtu.dk \\
\hline 75 & Sten Mortensen & stm@fvst.dk \\
\hline 76 & Jørgen Westergaard & adc-consult@youmail.dk \\
\hline \multicolumn{3}{|l|}{ Estonia } \\
\hline 77 & Maarja Kristian & maarja.kristian@vet.agri.ee \\
\hline & Ago Pärtel & agopartel@gmail.com \\
\hline \multicolumn{3}{|l|}{ Iceland } \\
\hline $\begin{array}{l}79 \\
\text { Ireland }\end{array}$ & Audur Arnthorsdottir & audur.arnthorsdottir@mast.is \\
\hline 80 & Lena Englund & lena.englund@ec.europa.eu \\
\hline \multicolumn{3}{|l|}{ Latvia } \\
\hline 81 & Edvins Olsevskis & edvins.olsevskis@pvd.gov.lv \\
\hline \multicolumn{3}{|l|}{ Lithuania } \\
\hline 82 & Kazimieras Lukauskas & K.Lukauskas@oie.int \\
\hline 83 & Vidmantas Paulauskas & vpaulauskas@vet.It \\
\hline \multicolumn{3}{|l|}{ Norway } \\
\hline $\begin{array}{l}84 \\
\text { Poland }\end{array}$ & Siri Løtvedt & simlo@mattilsynet.no \\
\hline $\begin{array}{l}85 \\
\text { Sweden }\end{array}$ & Krzysztof Jażdżewski & krzysztof.jazdzewski@wetgiw.gov.pl \\
\hline 86 & Mikael Leijon & mikael.leijon@sva.se \\
\hline 87 & Malin Grant & malin.grant@jordbruksverket.se \\
\hline 88 & Johan Waldner & johan.waldner@dv.sjv.se \\
\hline
\end{tabular}

\section{Figure 2: Participants of the seminar}

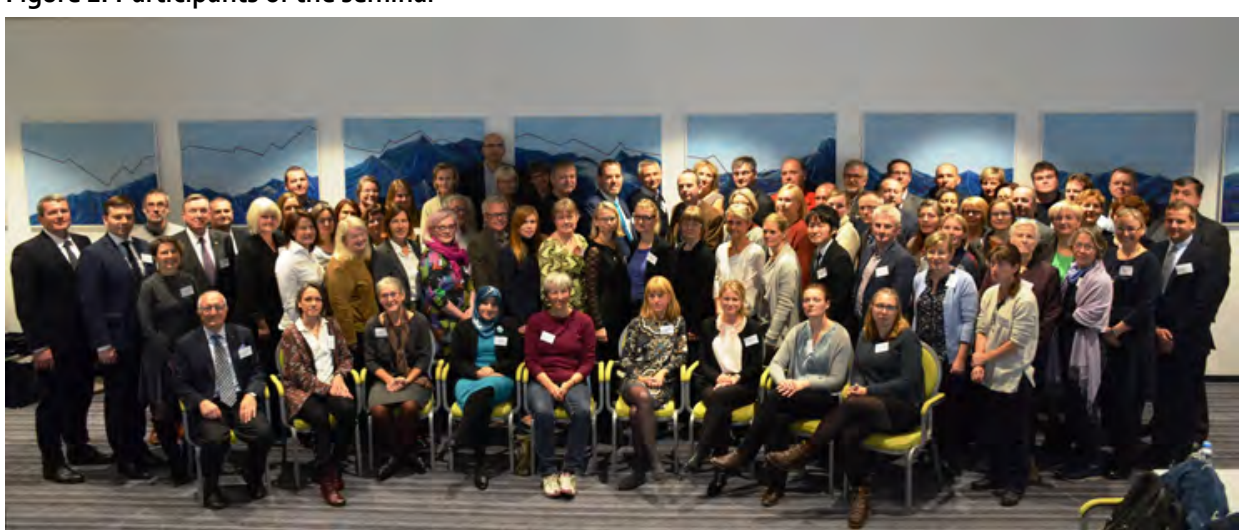




\section{Seminar photos}

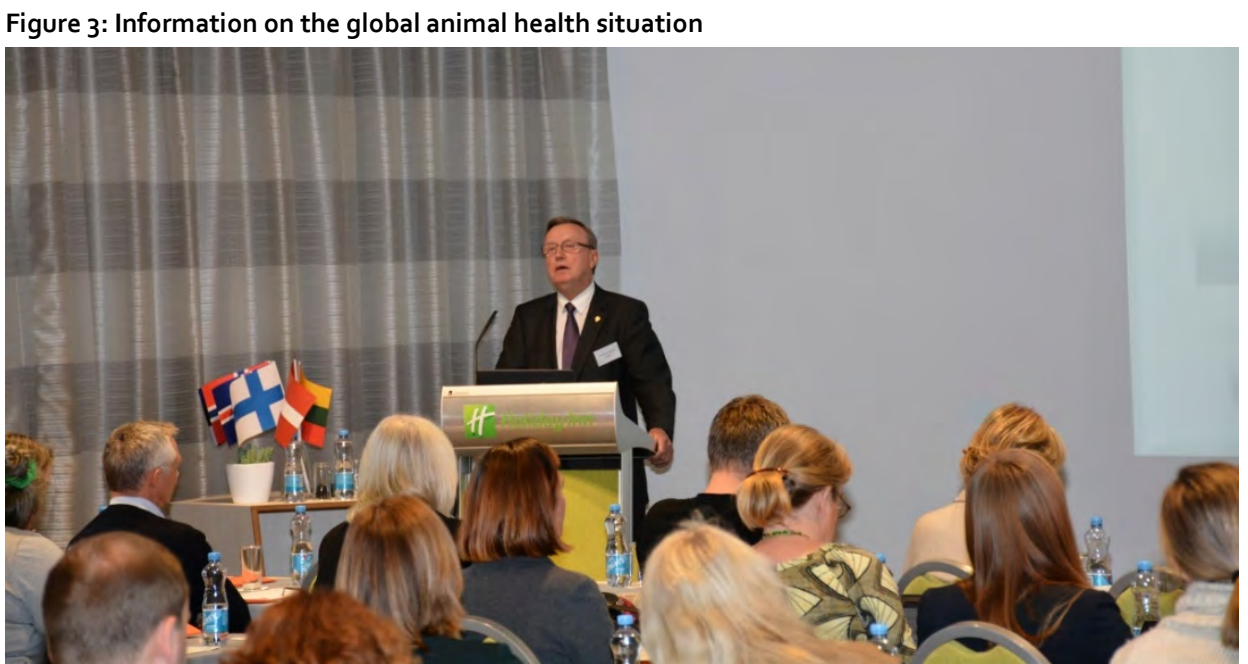

Figure 4: An active listening audience

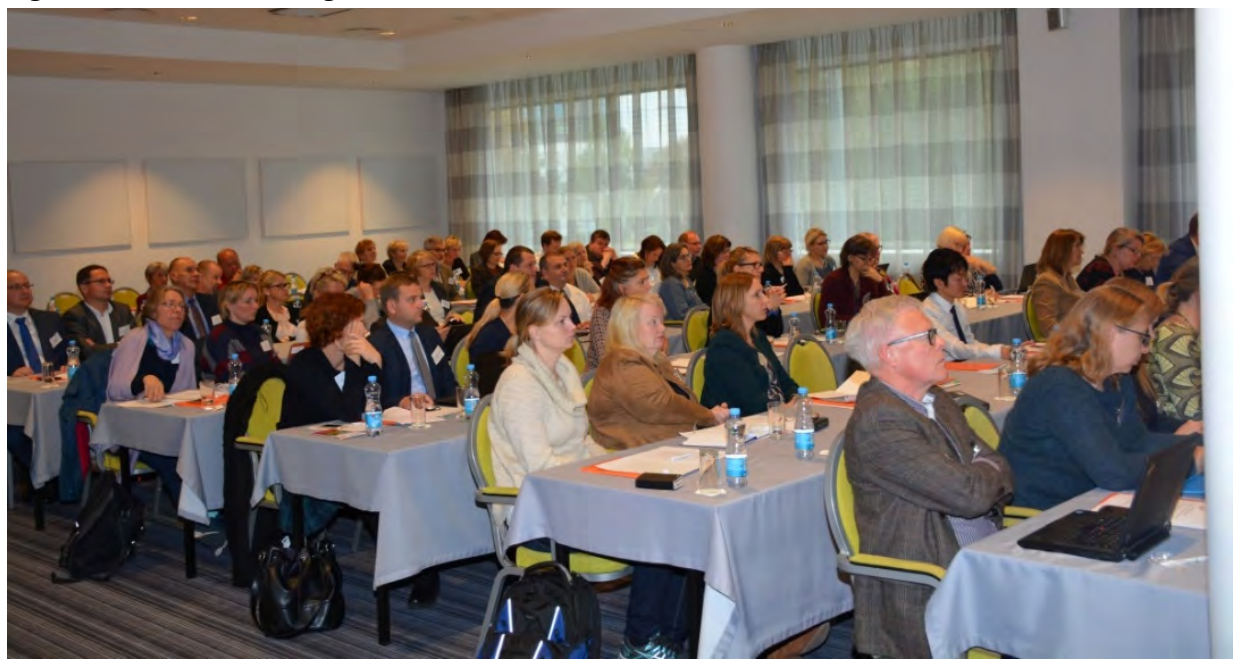


Figure 5: The panel at work

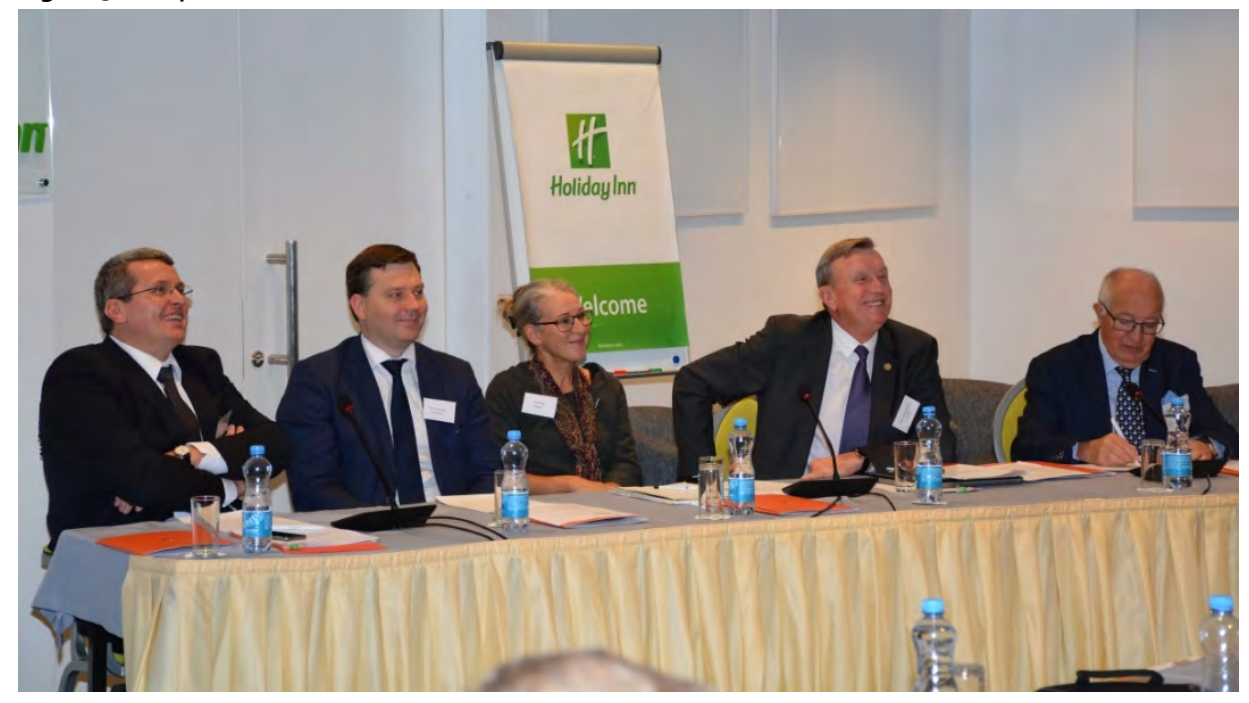




\section{Annex 2 - Nordic-Baltic cooperation}

Memorandum of Understanding on a Nordic-Baltic Animal Health Emergency Reserve and on Nordic-Baltic Veterinary Contingency Planning Studies among:

- Denmark: The Danish Veterinary and Food Administration.

- Estonia: The Veterinary and Food Board of Estonia.

- Finland: The Ministry of Agriculture of Finland.

- Iceland: The Agricultural Authority of Iceland.

- Latvia: The Food and Veterinary Service of Latvia.

- Lithuania: The State Food and Veterinary Services of the Republic of Lithuania.

- Norway: The Norwegian Food Safety Authority.

- Sweden: The Swedish Board of Agriculture.

Referred to as "the Participants" collectively and "the Participant" individually.

The Participants wish to strengthen the collaborative relationship between them, for the purpose of fighting the spread of serious animal diseases, by forming:

- A Nordic Animal Health Emergency Reserve, to provide support and assistance to a participant in response to an animal disease outbreak emergency; where the resources of the country affected by the outbreak are not sufficient to meet the needs of the country affected by the outbreak emergency.

- A platform for Nordic-Baltic Veterinary Contingency Planning Studies, to support study visits and training sessions facilitating enhanced animal disease preparedness in the Nordic-Baltic Region.

\section{Chapter I-The Nordic-Baltic Animal Health Emergency Reserve}

The country affected by the disease is referred to as "Recipient Country" and the country providing assistance as "the Donor Country".

The participants have reached the following understanding

- In the event of an animal disease outbreak, the Participants intend to provide, when requested in writing and within their resource capabilities, skilled and competent personnel to respond to the animal disease situation in the affected country. This arrangement has mutual benefits in that the Recipient Country 
receives skilled assistance, while Donor Country personnel gain valuable experience. Skilled and competent personnel include, but are not limited to: Veterinarians and Veterinary Specialists, Animal Health Technicians, Laboratory Diagnosticians and Emergency Managers. Criteria for skilled and competent personnel are established by the Recipient Country.

- Personnel of Donor Countries are under the supervision of the Recipient Country's official representative and will abide by the public service code of conduct and all regulations brought to their attention by the responsible Recipient Country's official representative. The Recipient Country will provide full and effective briefings on these requirements.

- Personnel of Donor Countries will keep their employment contract intact, with all rights and insurances that it comprises also when personnel are working abroad. The Donor Countries will pay the salary of personnel and expenses related to travel of personnel to and return from Recipient Country. The Recipient Country will cover the costs for accommodation and for travel within the Recipient Country.

- The Recipient Country will provide for work permit and authorization of veterinarians.

- Guidelines, which may be used in relation to a request for assistance within the framework the Nordic-Baltic Animal Health Reserve are shown in Annex 1.

\section{Chapter II - The platform for Nordic-Baltic Veterinary Contingency Planning Studies}

The country seeking assistance in obtaining training of personnel is referred to as "Beneficiary Country" and the country providing the assistance as "Host Country".

The participants have reached the following understanding

- Assistance for training relates to study visits and field visits covering areas within the context of animal disease prevention, control and eradication and zoonotic diseases.

- A request for assistance will usually involve from 1-3 officials from the beneficiary country who in the host country shall stay for an indicative duration of two to five days.

- Personnel of the Beneficiary Country will keep their employment contract intact, with all rights and insurances that it comprises. The Beneficiary Country will pay the salary, travel expenses and accommodation.

- An application form which may be used in relation to the Nordic-Baltic Veterinary Contingency Planning Studies is shown in Annex 2. 


\section{Chapter III - Agreement interpretation}

With regard to the implementation of the agreement the participants have reached the following understanding:

- Should there be differences of opinion and interpretation of this agreement or the activities and work hereunder; the Participants will resolve such differences in an amicable manner.

- This agreement may only be amended by agreement in writing of all the Participants, specifying the dates on which such amendments will enter into effect.

- This agreement enters into effect on the date of its execution and will remain in effect for a period of five years, and will be automatically extended for a further five year period, unless the Participants agree otherwise.

- Termination of this agreement will not terminate or affect completion of any activities or work being carried on under this agreement at the date of termination.

- If at any time this agreement no longer reflects the intentions of a Participant, then the Participant is to promptly notify the other Participants in writing.

\section{Signed}

- Denmark: Per Henriksen, Chief Veterinary Officer. The Danish Veterinary and Food Administration.

- Estonia: Olev Kalda, Chef Veterinary Officer. The Veterinary and Food Board of Estonia.

- Finland: Taina Aaltonen, Chief Veterinary Officer. The Ministry of Agriculture of Finland.

- Iceland: The Agricultural Authority of Iceland.

- Latvia: Māris Balodis, Chief Veterinary Officer. The Food and Veterinary Service of Latvia.

- Lithuania: Jonas Milius, Chief Veterinary Officer. The State Food and Veterinary Services of the Republic of Lithuania.

- Norway: Kristina Landsverk, Chief Veterinary Officer. The Norwegian Food Safety Authority.

- Sweden: Ingrid Eilertz, Chief Veterinary Officer. The Swedish Board of Agriculture. 


\section{Annexes}

- Annex 1. Guidelines which may be used in relation to the Nordic-Baltic Animal Health Reserve:

- Guidelines related to a request for assistance - Animal Health Emergency.

- Recipient Country.

- Donor Country.

- Description of area/topic where assistance is requested.

- Skills and competence of personnel including language knowledge needed for performing duties.

- Needed number of skilled and competent personnel.

- Tentative period where assistance is required.

- Location(s) designated for posting of personnel from Donor Country.

- Contact person in Recipient Country.

- Annex 2. Application form which may be used in relation to the Nordic-Baltic Veterinary Contingency Planning Studies.

- Application form for training/study

- Project title: Study/field visit on.

- Beneficiary Country.

- Host Country.

- Objective of the training/visit.

- Time

- Preferred date of the training/study.

- Year.

- Week.

- Number of days.

- Language knowledge

- 1st language.

- 2nd language.

- 3 rd language.

- Transport and accommodation preferences

- Transport from the Beneficiary country to the host country will be by.

- Would like the host country to book accommodation.

- Details of the person(s) participating in the training/study visit. 


\section{Coordinator}

Table 7: Person 1 - Coordinator

Title (Mr., Mrs.)
First Name:
Surname:
Ministry or Institution:
Administrative Unit:
Function:
Office address ( Street/number):
Post code:
City:
Office Tel:
Mobile phone:
E-mail

\section{Table 8: Person 2}

Title (Mr., Mrs.)

First Name:

Surname:

Ministry or Institution:

Administrative Unit:

Function:

Office address ( Street/number):

Post code:

City:

Office Tel:

Mobile phone:

E-mail

\section{Table 9: Person 3}

Title (Mr., Mrs.)

First Name:

Surname:

Ministry or Institution:

Administrative Unit:

Function:

Office address ( Street/number):

Post code:

City:

Office Tel:

Mobile phone:

E-mail 



\title{
Annex 3-African swine fever in the Baltic countries in 2015
}

\author{
Introduction
}

African swine fever (ASF) entered in the spring of 2007 countries in the Caucasus region. The disease spread via the Russian Federation, Ukraine and Belarus to the Baltic countries where it appeared in 2014 with multiple entrances linked to wild boar movements from endemic areas.

The disease situation in 2015 was as shown in table 10.

Table 10: African swine fever (ASF) recorded in 2015 in the Baltic countries Country Number of ASF outbreaks in domestic pigs Number of ASF cases detected in wild boar

$\begin{array}{ll}18 & 723 \\ 10 & 753 \\ 13 & 111\end{array}$

The Baltic countries do all apply the Stamping-out policy with regard to African swine fever and experiences gained in 2015 from: depopulation of domestic pig herds, cleansing and disinfection of farms and repopulation of farms are described in brief below.

\section{Legislative aspects}

The provisions for the measures to be applied during suspicion and confirmation of ASF in domestic pigs are laid down in Council Directive 2002/60/EC and the measures related to diagnostic procedures and to the killing of pigs are laid down in Commission Decision 2003/422/EEC and Council Regulation (EC) No. 1099/2009, respectively.

\section{Depopulation of pig farms}

The legal requirements to depopulation - the process of killing animals for public health, animal health, animal welfare or environmental reasons under supervision of the competent authority - are laid down in Council Regulation (EC) No 1099/2009 on the protection of animals at time of killing.

At the time of depopulation the competent authority takes into account: animal behavioral considerations, human behavior considerations, use of restraining 
equipment, stunning methods, and killing methods. The depopulation is only carried out by persons with the appropriate level of competence and in accordance with in advance approved standard operating procedures.

With the objective of having depopulation without causing the animals any avoidable pain, distress or suffering the legislation contains provisions for certain stunning and killing methods including: mechanical methods, electrical methods, gas methods and other methods.

The methods listed in the legislation have all been used in the Baltic countries and information of their application is shown in table 11.

Table 11: Stunning and killing methods used in 2015 in relation to African swine fever outbreaks

\begin{tabular}{|c|c|c|c|c|c|}
\hline $\begin{array}{l}\text { Country } \\
\text { Number of } \\
\text { Outbreaks } 2015\end{array}$ & Mechanical & Electrical & Gas & Lethal injections & $\begin{array}{r}\text { Pigs dead at } \\
\text { time of } \\
\text { confirmation }\end{array}$ \\
\hline Estonia: 18 & 1 & & 12 & 3 & 2 \\
\hline Latvia: 10 & 9 & 1 & & 2 & 1 \\
\hline Lithuania: 13 & 2 & & 10 & & 1 \\
\hline
\end{tabular}

The requirements to the timing for depopulation are stipulated in the legislation by the text: "all pigs on the holding are to be killed without delay under official supervision and in such a way as to avoid the risk of African swine fever virus spreading during transport or killing". From an epidemiological point of view it is evident that "killing without delay" and "avoid the spread of virus" are two important factors. However, "killing without delay" does not play with regard to ASF the same importance as during a foot and mouth disease outbreak.

Information on the time of depopulation related to African swine fever outbreak is given in table 12.

Table 12: Depopulation and time factor during African swine fever outbreaks in 2015 in the Baltic countries

\begin{tabular}{l|r|r|r|r}
$\begin{array}{l}\text { Country } \\
\text { Number of } \\
\text { Outbreaks } 2015\end{array}$ & $\begin{array}{r}\text { Depopulation on } \\
\text { date of disease } \\
\text { confirmation }\end{array}$ & $\begin{array}{r}\text { Depopulation on } \\
\text { date of disease } \\
\text { confirmation + 1 }\end{array}$ & $\begin{array}{r}\text { Depopulation on } \\
\text { date of disease } \\
\text { confirmation + } 2\end{array}$ & $\begin{array}{r}\text { Depopulation on } \\
\text { date of disease } \\
\text { confirmation }+>\mathbf{2}\end{array}$ \\
\hline Estonia: 18 & 4 & 6 & 4 & 4 \\
Latvia: 10 & 4 & 5 & 1 & 1 \\
Lithuania: 13 & 8 & 4 & 1 & \\
\hline
\end{tabular}

\section{Cleansing and disinfection}

The African swine fever virus can survive at low temperatures in long periods; it can retain infectivity in chilled meat for months and in frozen meat for years. By use of heat the virus can be inactivated by $56^{\circ} \mathrm{C} / 70$ minutes or $60^{\circ} \mathrm{C} / 20$ minutes (1). In the environment it is stable at $\mathrm{pH} 4-12$. With a rather resistance virus great attention must be paid to the cleansing and disinfection following outbreaks. Common disinfections are 
ineffective against the ASF- virus; disinfections listed by OIE (1) for use include sodium hydroxide, hypochlorites, formalin, ortho-phenylphenol and iodine compounds.

The principles and procedures for cleansing and disinfection are outline in the legislation and the cleansing and disinfection of a holding after an outbreak includes:

- A preliminary cleansing and disinfection.

- A final cleansing and disinfection.

All disinfectants and their concentrations used during the cleaning and disinfection work have been approved by the competent authority and used under official supervision. The trade name(s) for the disinfections used were: Halamid ${ }^{\circledast}$ in Estonia; Komcid ${ }^{\circledR}$ and Germicidan ${ }^{\circledR}$ in Latvia and Ecocid ${ }^{\circledR}$ in Lithuania. All have active components against the ASF - virus.

\section{Repopulation of farms}

The legislation outlines that repopulation shall not take place until at least 40 days after completion of the cleansing, disinfection and if necessary disinsectisation operations in the holding. Furthermore, the reintroduction of pigs shall take account of:

- The epidemiological situation with regard to the disease transmission in the area.

- The type of farming practised on the holding.

Special provisions are laid down for holdings situated in areas where the occurrence of disease has been linked to the presence of vectors and at farm level conditions are given for open-air-holdings and other type of holdings.

In the Baltic countries a number of small holdings were never repopulated and information on the repopulation which took place is shown in table 13.

Table 13: Repopulation of holdings after outbreaks of African swine fever

\begin{tabular}{l|r|r|r|r|}
$\begin{array}{l}\text { Country } \\
\text { Number of } \\
\text { Outbreaks 2015 }\end{array}$ & $\begin{array}{r}\text { Holdings } \\
\text { Repopulated } \\
\text { (November 2016) }\end{array}$ & Partly Repopulated & Full repopulation & $\begin{array}{r}\text { Months after } \\
\text { completion of } \\
\text { cleansing \& } \\
\text { disinfection }\end{array}$ \\
\hline Estonia: 18 & 5 & 5 & & $2-12$ \\
Latvia: 10 & 3 & 2 & 1 & $6-8$ \\
Lithuania: 13 & 1 & & 1 & 8 \\
\hline
\end{tabular}




\section{General observations and conclusions}

The data shown in table 10 indicates that African swine fever is endemic in the wild boar population and a good biosecurity at pig farms is important for preventing the disease entering the domestic pig population.

The measures outlined in the EU-legislation have been applied in the Baltic countries to control and eradicate ASF in domestic pigs. The work related to depopulation, cleansing and disinfection and repopulation has been carried out in a successful way: NO RECRUDESCENCE has occurred at any holding. 


\section{Annex 4-Publications}

The Nordic-Baltic Veterinary Contingency Group has since 2007 published a number of documents on different aspects of contingency planning within the area of animal health. Information on the publications is shown in the table below.

Table 14: Publications prepared by the Nordic-Baltic Veterinary Contingency group

\begin{tabular}{|c|c|c|}
\hline $\begin{array}{l}\text { Year of } \\
\text { Publication }\end{array}$ & Name of document & Issued by* \\
\hline 2016 & $\begin{array}{l}\text { Biosecurity and livestock production } \\
\text { The proceedings of a Nordic-Baltic seminar on biosecurity highlightning experiences gained in livestock } \\
\text { production, and future challenges with special reference to motivation, training and economic aspects, 6-8 } \\
\text { May 2014, Rimbo, Sweden } \\
\text { TemaNord } 2016-504 \text { ISSN } 0908-6692\end{array}$ & $\begin{array}{l}\text { Nordic } \\
\text { Council }\end{array}$ \\
\hline 2015 & $\begin{array}{l}\text { TROUT } 2013 \text { - simulating VHS outbreaks: Report on Exercise TROUT 2013-Implementation of and } \\
\text { activities related to a Viral Haemorrhagic Septicaemia (VHS) simulation exercise for the Nordic and Baltic } \\
\text { Countries conducted 4th-5th December 2013, Bergen, Norway } \\
\text { TemaNord 2014:571 ISSN 0908-6692 }\end{array}$ & $\begin{array}{l}\text { Nordic } \\
\text { Council }\end{array}$ \\
\hline 2014 & $\begin{array}{l}\text { Wildlife and Infectious Animal Diseases The Proceedings of a Nordic-Baltic seminar on the role of the } \\
\text { wildlife as reservoir and/or spread of infectious animal diseases in the coastal areas of countries bordering } \\
\text { the Baltic Sea 2-3 October 2013, Gdansk, Poland } \\
\text { Tema Nord 2014:508 ISSN 0908-6692 }\end{array}$ & $\begin{array}{l}\text { Nordic } \\
\text { Council }\end{array}$ \\
\hline 2014 & $\begin{array}{l}\text { Contingency Planning for Animal Diseases The Proceedings of a Nordic-Baltic Seminar on "Contingency } \\
\text { Planning for the next Decade" held 19-20 September } 2012 \text { Helsinki, Finland } \\
\text { TemaNord 2014:509 ISSN 0908-6692 }\end{array}$ & $\begin{array}{l}\text { Nordic } \\
\text { Council }\end{array}$ \\
\hline 2013 & $\begin{array}{l}\text { Operational Expert Groups for Animal Diseases Report on Ad-Hoc meeting on the operational expert groups for } \\
\text { animal diseases: How to maintain expertise? Copenhagen, 3-4 December } 2012 \\
\text { Nordic Working Papers NA2013:926 }\end{array}$ & $\begin{array}{l}\text { Nordic } \\
\text { Council }\end{array}$ \\
\hline 2013 & $\begin{array}{l}\text { Strengthening and Adaption of the Preventive Measures to Existing Risks of African Swine Fever } \\
\text { Introduction from Eastern Neighbouring Countries to Nordic - Baltic Region. Report on Workshop 29-31 } \\
\text { October 2012, Latvia, Sigulda } \\
\text { Word Document }\end{array}$ & Latvia \\
\hline 2012 & $\begin{array}{l}\text { Exercise AUTUMN-2011, Nordic - Baltic African Swine Fever Exercise, October } 2011 . \\
\text { Nordic Working Papers NA2013:907 }\end{array}$ & $\begin{array}{l}\text { Nordic } \\
\text { Council }\end{array}$ \\
\hline 2010 & $\begin{array}{l}\text { Nordic-Baltic Seminar on Risk Based Animal Health Surveillance and Contingency planning, 1st-3rd } \\
\text { September } 2010 \\
\text { PDF file }\end{array}$ & Sweden \\
\hline 2010 & $\begin{array}{l}\text { Seminar on the Importance of Vectors in the Spread of Animal Disease Today and in the Future, Riga, 13th } \\
\text { and 14th of October } 2009 \\
\text { Proceedings PDF-file }\end{array}$ & Sweden \\
\hline 2010 & $\begin{array}{l}\text { Exercise SPRING, Nordic Baltic West Nile Fever Exercise 2009, 3rd June } 2009 \\
\text { Proceedings PDF-file }\end{array}$ & Sweden \\
\hline 2009 & $\begin{array}{l}\text { Nordic-Baltic Bluetongue Simulation Exercise "HOT-AIR" 14th-16th May } 2008 \\
\text { Report }\end{array}$ & Norway \\
\hline
\end{tabular}


involving the five Nordic countries J.M. Westergaard, C.B. Andersen \& S. Mortensen

Rev. sci. tech. Off. int. Epiz., 2008, 27 (3), 751-758

2007

Seminar on Risk Analysis: Risk Assessment, Risk Management and Risk Communication with special Reference to infectious animal diseases.In Oslo, Gardermoen, 3rd-4th of December 2007.

Norway

Proceedings

Note: All publications prepared by the Nordic-Baltic Veterinary Contingency Group and published by the Nordic Council are available on: www.norden.org/nordpub; publications not issued by the Nordic Council may be available from the National Veterinary Administrations of the Nordic Baltic countries. 
Nordic Council of Ministers

Nordens Hus

Ved Stranden 18

DK-1061 Copenhagen K

www.norden.org

\section{Animal Health Contingency Planning}

Contingency planning in the area of animal health is all about preparing for threats and outbreaks of exotic disease, i.e. a disease not present in the country. The objective of contingency planning is to encourage livestock keepers, producers and manufacturers of food and feed, veterinarians in the private and public sector and relevant governmental institutions to think about major contingencies and possible response. The planning involves the development of contingency plans based on the four pillars: prevention, preparation, response and recovery and the conduct of simulation exercises.

This report presents an overview of contingency planning related to animal diseases, preparedness for natural disasters, experiences gained from outbreaks of African swine fever in Baltic and Eastern European countries and contains the Memorandum of Understanding on a Nordic-Baltic Animal Health Emergency Reserve and on Nordic-Baltic Veterinary Contingency Planning Studies. 